\title{
10. PROVENANCE OF PLEISTOCENE AND PLIOCENE SAND AND SANDSTONE, ODP LEG 141, CHILE MARGIN ${ }^{1}$
}

\author{
Kathleen M. Marsaglia, ${ }^{2}$ Xavier V. Torrez, ${ }^{2}$ Ivan Padilla, ${ }^{2}$ and Karl C. Rimkus ${ }^{2}$
}

\begin{abstract}
The intersection of the Nazca, Antarctic, and South American tectonic plates is a trench-ridge-trench triple junction (Chile Triple Junction, or CTJ) at latitude $46^{\circ} \mathrm{S}$ along the Chilean margin of South America. Pliocene-Pleistocene sand and sandstone samples were collected during Leg 141 from Sites 859 and 860 (located $10 \mathrm{~km}$ north of the CTJ), Site 863 (located a few km south of the CTJ), and Site 862 (located farther south on the Taitao Ridge). Sand detrital modes of 107 samples were determined using the Gazzi-Dickinson method of point counting. Sand compositions are fairly uniform, with the following mean values: QFL\%Q 31, QFL\%F 35, and QFL\%L 34. These sediments have a dissected arc provenance, reflecting extensive onshore erosion of quartzose Paleozoic metasedimentary basement rocks and the Mesozoic Patagonian batholith in conjunction with late Cenozoic glaciation and tectonism. The lithic component is dominantly intermediate to mafic volcaniclastic debris derived from arc volcanoes and perhaps near-trench volcanic centers on the Taitao Peninsula. Sites south of the CTJ show higher metamorphic and sedimentary lithic proportions, probably due to uplift and erosion in the Taitao Peninsula region during northward migration of the CTJ.
\end{abstract}

\section{INTRODUCTION}

The intersection of the Nazca, Antarctic, and South American plate margins is marked by a trench-ridge-trench triple junction located near the Taitao Peninsula along the Chilean margin of South America (Fig. 1; Herron et al., 1981; Cande and Leslie, 1986; Cande et al., 1987). Plate reconstructions by Pilger (1978) and Cande et al. (1982) indicate that this triple junction migrated northward along the coast of southern Chile, starting at approximately $14 \mathrm{Ma}$. They propose that alternate ridge and transform segments were sequentially subducted: first a series of long ridge and short transform segments (14-6 Ma), followed by a series of short ridge and long transform segments $(6-0 \mathrm{Ma})$.

The effects of ridge subduction were investigated based on five sites drilled along this margin on Ocean Drilling Program (ODP) Leg 141 (Fig. 1): Sites 859,860 , and 861 along a transect at the northern end of the subducting ridge segment, approximately $10 \mathrm{~km}$ north of the Chile Triple Junction; Site 863 a few kilometers south of the triple junction on an intensely deformed section of the accretionary wedge, just above the subducted ridge crest; and Site 862, farther south, on the Taitao Ridge, a possible extension of the Taitao forearc ophiolite complex (Forsythe and Nelson, 1985), or a fragment of oceanic crust (Leslie, 1986). Subduction of a spreading ridge occurred at approximately 50 ka near Site 862 (Bangs et al., 1992). All of the sediments recovered on Leg 141 are younger than the Taitao ophiolite, but in part they are synchronous with its sedimentary cover (R. Forsythe, pers. comm., 1993).

Schematic stratigraphic sections for Leg 141 sites are shown in Figures 2 and 3 ; they consist of hemipelagic mud and mudstone with minor sand, sandstone, gravel, and conglomerate. The coarse sediments are interpreted by Behrmann, Lewis, Musgrave, et al. (1992) as the deposits of high- and low-density turbidity currents and debris flows associated with onshore continental glaciation, which extended to the shelf edge during the early Pleistocene (Clapperton, 1990; Rabassa and Clapperton, 1990). At Site 859, a thin section of folded upper Pleistocene trench-slope cover unconformably overlies a thick sequence of flat-bedded to severely disrupted mud and mudstone that

'Lewis, S.D., Behrmann. J.H.. Musgrave, R.J., and Cande, S.C. (Eds.), 1995, Proc. ODP, Sci. Resuits, 141: College Station. TX (Ocean Drilling Program).

Department of Geological Sciences, The University of Texas at El Paso, El Paso, TX 79968, U.S.A. may represent an accretionary wedge. This sequence contains less than $1 \%$ coarse clastic material. Upslope from Site 859 , at Sites 860 and 861 , progressively thicker and more complete Pleistocene trenchslope sections overlie Pliocene mud and mudstone (Fig. 2). The only lower Pliocene sediments were encountered at Site 860 in the lower faulted section. On the Taitao Ridge, at Site 862 (Fig. 3), volcanic basement is draped by a thin sequence of clayey siltstone with finesand layers, interpreted as turbidites and possible contour-current deposits (Behrmann, Lewis, Musgrave, et al., 1992). The most dramatic sedimentary sequence was recovered at Site 863, where approximately $500 \mathrm{~m}$ of near-vertical sandstone turbidite beds were cored (Fig. 3). Due to the steep dip, the total stratigraphic section represented at this site may be significantly less than the cored interval depicted in Figure 3. The complex structural history at this site indicates normal, reverse, and strike-slip fault movement, which can be ascribed to recent subduction of a spreading ridge at this location (Behrmann, Lewis, Musgrave, et al., 1992). The purpose of this study was to determine the detrital modes of Pleistocene and Pliocene sandy sediments recovered on Leg 141 and to relate them to the tectonic evolution of this margin.

\section{METHODS}

Samples of sandy sediment were taken aboard ship from cores recovered at Sites $859,860,861,862$, and 863 . Unconsolidated samples were air dried and lightly sieved by hand for the sand fraction $(0.0625-2 \mathrm{~mm})$. Sand concentrates were then epoxied to glass slides and ground to $30 \mu \mathrm{m}$ thickness. All thin sections were subsequently stained for both calcium- and potassium-rich feldspars, using the method outlined in Marsaglia and Tazaki (1992). Where possible, 400 points were counted on each section using the GazziDickinson method, which minimizes the effects of grain-size variation on composition (Dickinson, 1970; Ingersoll et al., 1984). Grid spacings were used that maximized coverage of the thin section and were larger than the maximum grain size.

Counted grains were placed into 40 monomineralic and polymineralic compositional categories (Table 1) with textural subdivision of volcanic lithic types based on Dickinson (1970) and Marsaglia (1991, 1992). Point-count categories and recalculated parameters are defined in Table 1, raw point-count data are presented in Appendix 1, and recalculated parameters in Appendix 2. Recalculated parameters, means, and standard deviations were calculated using a Lotus 123 spreadsheet program. 


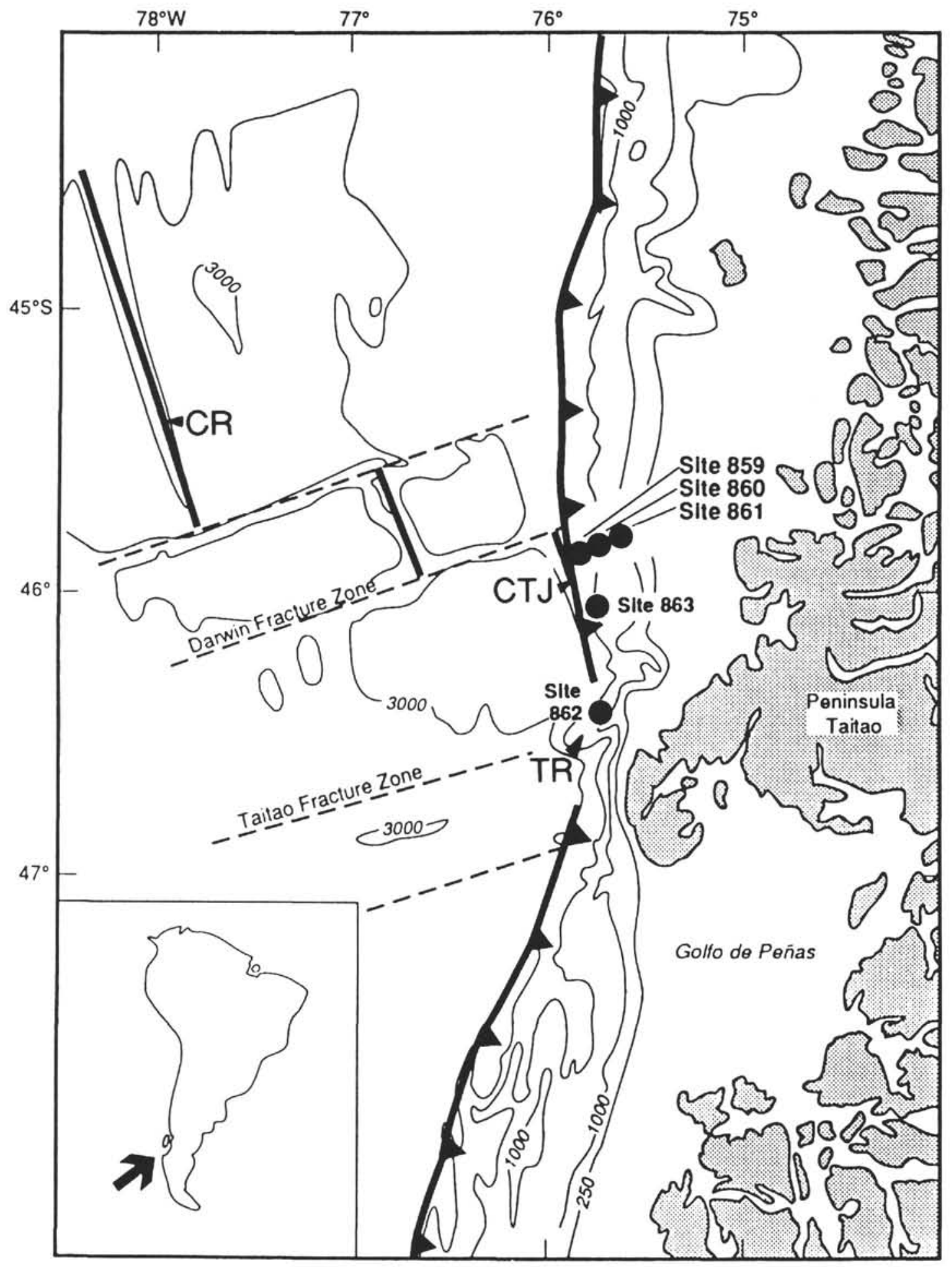

Figure 1. Location map for Leg 141 sites from Behrmann, Lewis, Musgrave, et al. (1992). Heavy barbed lines denote subduction zones, heavy plain lines denote ridge segments $(\mathrm{CR}=$ Chile Ridge $)$, and light dashed lines indicate fracture zones. $\mathrm{TR}=$ Taitao Ridge; $\mathrm{CTJ}=\mathrm{Chile}$ Triple Junction.

\section{GENERAL DESCRIPTION}

Roughly $50 \%$ of the samples taken from Sites 859,860 , and 861 were unsuitable for this study because they were too fine grained or poorly sorted, and they lacked sufficient sand-sized material to analyze. Site 861 was especially sand-poor, with no sufficiently sandy intervals sampled below $260 \mathrm{~m}$. Grain size was less of a problem with samples from Sites 862 and 863 , where roughly $75 \%$ of the samples were counted. Sample intervals for counted samples are shown in the stratigraphic columns of Figures 2 and 3.

At the northern transect sites (Sites 859, 860, and 861) and at Site 862 , the sand fraction is predominantly very fine, with minor finesand intervals (Appendix 1). At Site 863, the mean grain size is somewhat larger, with fine sand in the uppermost sections cored at Holes $863 \mathrm{~A}$ and $863 \mathrm{~B}$. Fine sand dominates the upper sections of both Holes 863A (0-259 mbsf) and 863B (326-457 mbsf), whereas the 
Table 1. Counted and recalculated parameters.

\begin{tabular}{|c|c|}
\hline \multicolumn{2}{|r|}{ Counted parameters } \\
\hline Qp & Polverystalline quartz \\
\hline Qm & Monocrystalline quartz. \\
\hline $\mathrm{P}$ & Plagioclase feldspar \\
\hline$P(A / D)$ & Altered or dissolved plagioclase \\
\hline $\mathrm{K}$ & Potassium feldspar \\
\hline Unst Feld & Unstained ( $\mathrm{Na}$ ?) feldspar \\
\hline Lvo & Other volcanic lithic (microcrystalline aggregate) \\
\hline Lvv & $\begin{array}{l}\text { Vitric volcanic lithic } \\
\text { brgl }=\text { brown glass } \\
\text { orbg = orange-brown glass } \\
\text { clgl }=\text { colorless glass } \\
\text { blgl }=\text { black glass } \\
\mathrm{A} / \mathrm{D}=\text { altered or dissolved glass }\end{array}$ \\
\hline Lvf & Volcanic lithic with felsitic texture \\
\hline Lvml & $\begin{array}{l}\text { Volcanic lithic with microlitic texture } \\
\text { brgl }=\text { brown glass } \\
\text { orbg }=\text { orange-brown glass } \\
\text { clgl }=\text { colorless glass } \\
\text { blgl }=\text { black glass } \\
\text { A/D }=\text { altered or dissolved glass }\end{array}$ \\
\hline LvI & $\begin{array}{l}\text { Voleanic lithic with lathwork lexture } \\
\text { brgl = brown glass } \\
\text { clgl }=\text { colorless glass } \\
\text { blgl }=\text { black glass } \\
\mathrm{A} / \mathrm{D}=\text { altered or dissolved glass }\end{array}$ \\
\hline $\operatorname{Lmv}$ & Metavolcanic lithic \\
\hline Lmm & Polycrystalline mica lithic \\
\hline $\mathrm{Lmt}$ & Quartz-mica tectonite lithic \\
\hline Lma & Quartz-feldspar-mica aggregate lithic \\
\hline Lmp & Phyllite lithic \\
\hline Lsi & Siltstone or sandstone(matrix/cement) sedimentary lithic \\
\hline Lsa & Argillite-shale lithic \\
\hline Lsc & Sedimentary carbonate lithic \\
\hline Lsch & Sedimentary chert or cherty argillite lithic \\
\hline Glau & Glauconite (Celadonite?) \\
\hline Org & Organic matter \\
\hline Bio Sil & Siliceous microfossil \\
\hline Bio Car & Calcareous microfossil or bioclas \\
\hline Carb & Carbonate minerals \\
\hline Mus & Muscovite \\
\hline Biot & Biotite \\
\hline $\mathrm{Chl}$ & Chlorite \\
\hline Op D & Opaque dense minerals \\
\hline NonOp D & Nonopague dense minerals \\
\hline Oth/Unk & Other miscellaneous and unidentified grains \\
\hline Total & Total points counted \\
\hline \multirow{3}{*}{$\begin{array}{l}Q=Q m+Q p \\
L=L m+L v+L s \\
L m=L m v+L m m+L m t+L m a+L m p\end{array}$} & $\mathrm{~F}=\mathrm{P}+\mathrm{P}(\mathrm{A} / \mathrm{D})+\mathrm{K}+$ Unst Felds \\
\hline & $L v=L v o+L v v+L v f+L v m i+L v I$ \\
\hline & $L s=L s a+L s c+L s i+L s c h$ \\
\hline \multicolumn{2}{|c|}{ Recalculated parameters } \\
\hline \multirow{3}{*}{$\begin{array}{l}\mathrm{QFL} \% \mathrm{Q}=100^{\circ} \mathrm{Q} /(\mathrm{Q}+\mathrm{F}+\mathrm{L}) \\
\mathrm{QFL} \% \mathrm{~F}=100^{*} \mathrm{~F} /(\mathrm{Q}+\mathrm{F}+\mathrm{L}) \\
\mathrm{QFL} \% \mathrm{~L}=100^{\circ} \mathrm{L} /(\mathrm{Q}+\mathrm{F}+\mathrm{L})\end{array}$} & $\mathrm{LmLvLs} \% \mathrm{Lm}=100^{*} \mathrm{Lm} / \mathrm{L}$ \\
\hline & $\mathrm{LmLvLs} / \mathrm{Lvv}=100 * \mathrm{Lv} / \mathrm{L}$ \\
\hline & $\mathrm{LmLvL} s \% \mathrm{Ls}=100^{\circ} \mathrm{Ls} / \mathrm{L}$ \\
\hline \multirow{2}{*}{\multicolumn{2}{|c|}{$\begin{array}{l}\left.\text { QmKP\% } / \mathrm{Qm}=100^{*} \mathrm{Qm} / \mid \mathrm{Qm}+\mathrm{K}+\text { Unst Feld }+\mathrm{P}+\mathrm{P}(\mathrm{A} / \mathrm{D})\right] \\
\mathrm{QmKP} / \%=100^{*}|\mathrm{P}+\mathrm{P}(\mathrm{A} / \mathrm{D})| / \mid \mathrm{Qm}+\mathrm{K}+\text { Unst Feld }+\mathrm{P}+\mathrm{P}(\mathrm{A} / \mathrm{D}) \mid \\
\left.\mathrm{QmKP} / \mathrm{K}=100^{*} \mathrm{~K} / \mathrm{Qm}+\mathrm{K}+\text { Unst Feld }+\mathrm{P}+\mathrm{P}(\mathrm{A} / \mathrm{D})\right]\end{array}$}} \\
\hline & \\
\hline \multicolumn{2}{|c|}{ 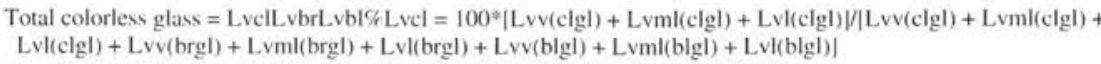 } \\
\hline \multirow{2}{*}{\multicolumn{2}{|c|}{$\begin{array}{l}\text { Total brown glass }=\text { LvclLvbrLvbl\%brgl }=100^{*}|L v v(b r g l)+L v m l(b r g l)+L v l(b r g l)| / L v v(c \mid g l)+L v m l(c \mid g l)+ \\
L v l(c \mid g l)+L v v(b r g l)+L v m l(b r g l)+L v l(b r g l)+L v v(b \mid g l)+L v m l(b \mid g l)+L v l(b|g|) \mid\end{array}$}} \\
\hline & \\
\hline \multicolumn{2}{|c|}{ 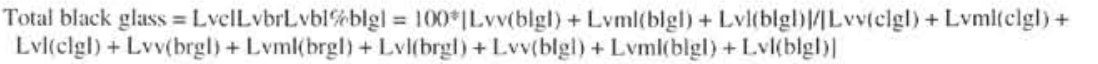 } \\
\hline \multicolumn{2}{|l|}{$\mathrm{Fr} \%$ Mica $=($ Musc + Biot + Chlor $) /($ Total $)$} \\
\hline \multicolumn{2}{|l|}{$\mathrm{Fr} \% \mathrm{D}=(\mathrm{OpD}+\mathrm{NonOpD}) /($ Total $)$} \\
\hline
\end{tabular}

lower sections are characterized by very fine sand (Hole 863A, 259288 mbsf; Hole $863 \mathrm{~B},>457 \mathrm{mbsf}$ ). See Diemer et al. (this volume) for more detailed grain-size analyses.

Sand grains range from very angular to rounded in any given sample, but are generally angular to subangular at Sites 859,860 , and 862 , angular at Site 862 , and subangular at Site 863 . The more easily abraded components, such as phyllitic and sedimentary lithics, tend to be more rounded.

\section{GRAIN TYPES}

Various monomineralic and lithic components are present in these samples (PIs. 1 through 4). Common monomineralic grains include quartz, potassium feldspar, plagioclase, and green amphibole. Rare monomineralic grains include albite (unstained $\mathrm{Na}$-feldspar), biotite, muscovite, chlorite, pyroxene, sphene, epidote, and opaque minerals. Monocrystalline quartz crystals exhibit both wavy and straight ex- 

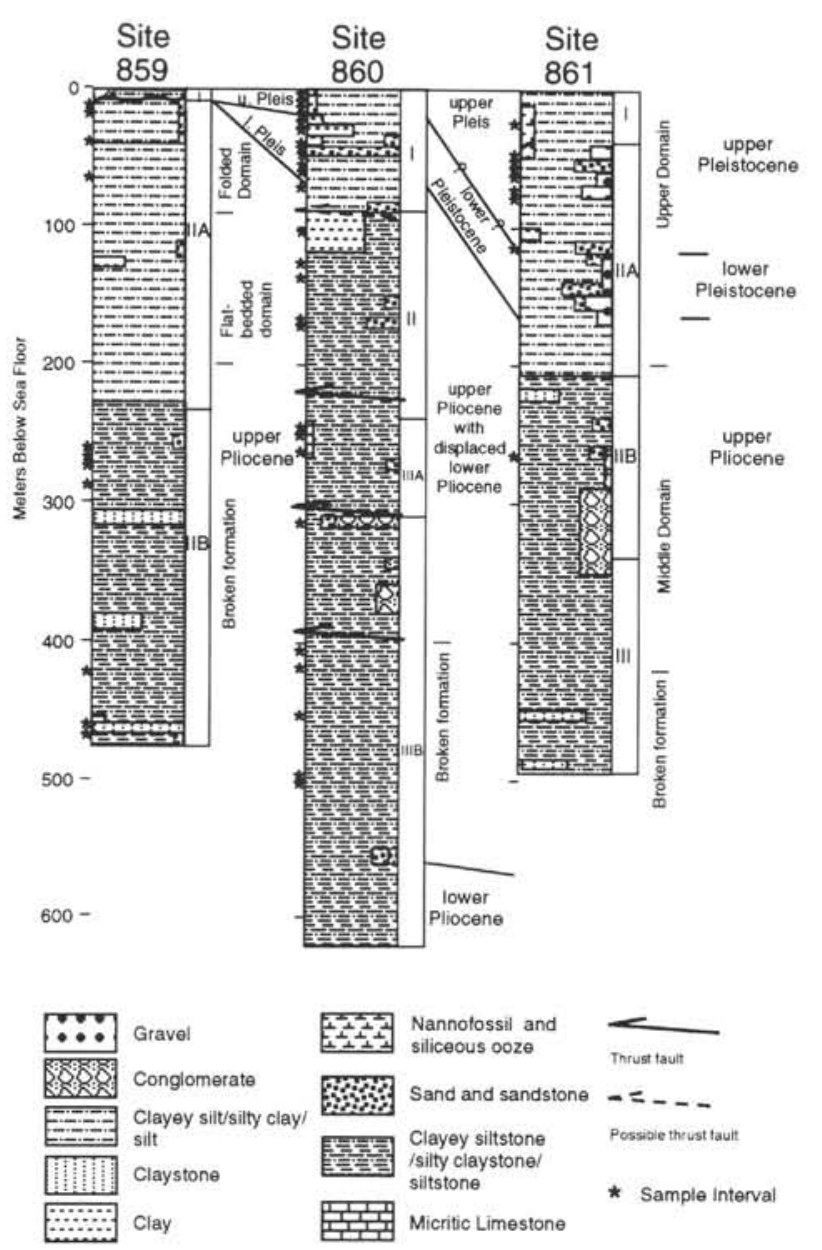

Figure 2. Schematic stratigraphic/structural columns for Leg 141 sites along the northern slope transect (Fig. 1). The coarse-grained intervals have been somewhat exaggerated in these sections. For more specific information on the sandy intervals analyzed in this study, see Appendix 1.

tinction; some have numerous inclusions. Some sand-size grains occur in igneous intrusive, coarse schist (or gneiss), and silicic volcanic fragments. Polycrystalline quartz is relatively rare. Plagioclase feldspar is the most common feldspar; it ranges from calcium-rich, unaltered grains to altered calcium-poor grains, partially replaced by sericite, clay minerals, or calcite.

Volcanic lithics are present in every sample, and are the predominant lithic type in most (Pls. 1, 2, and 4). These lithics are highly variable in composition and texture. Glassy fragments exhibit a range of colors in transmitted light: colorless, light $\tan$, tan, brown, dark brown, light gray, dark gray, and black. These range from nonvesicular to highly vesicular. The colorless glass takes a light calcium stain and occurs as stretched or woody pumice fragments. Brown sideromelane glassy fragments tend to be blocky and range from nonvesicular to moderately vesicular. Black tachylitic fragments tend to be nonvesicular. Microlitic fragments are characterized by silt-sized feldspar, pyroxene, and opaque microlites, whereas lathwork fragments contain sand-sized plagioclase, pyroxene, or rare olivine phenocrysts suspended in a vitric or microlitic groundmass. According to the Gazzi-Dickinson method of point counting, most laths are counted as monomineralic constituents. Glassy fragments were also distinguished if their groundmass had been altered or dissolved. Volcanic material is especially altered at Site 863B (see Prior et al., this volume). Other volcanic constituents include silt-sized aggregates of plagioclase and dense minerals, such as amphibole, pyroxene, and
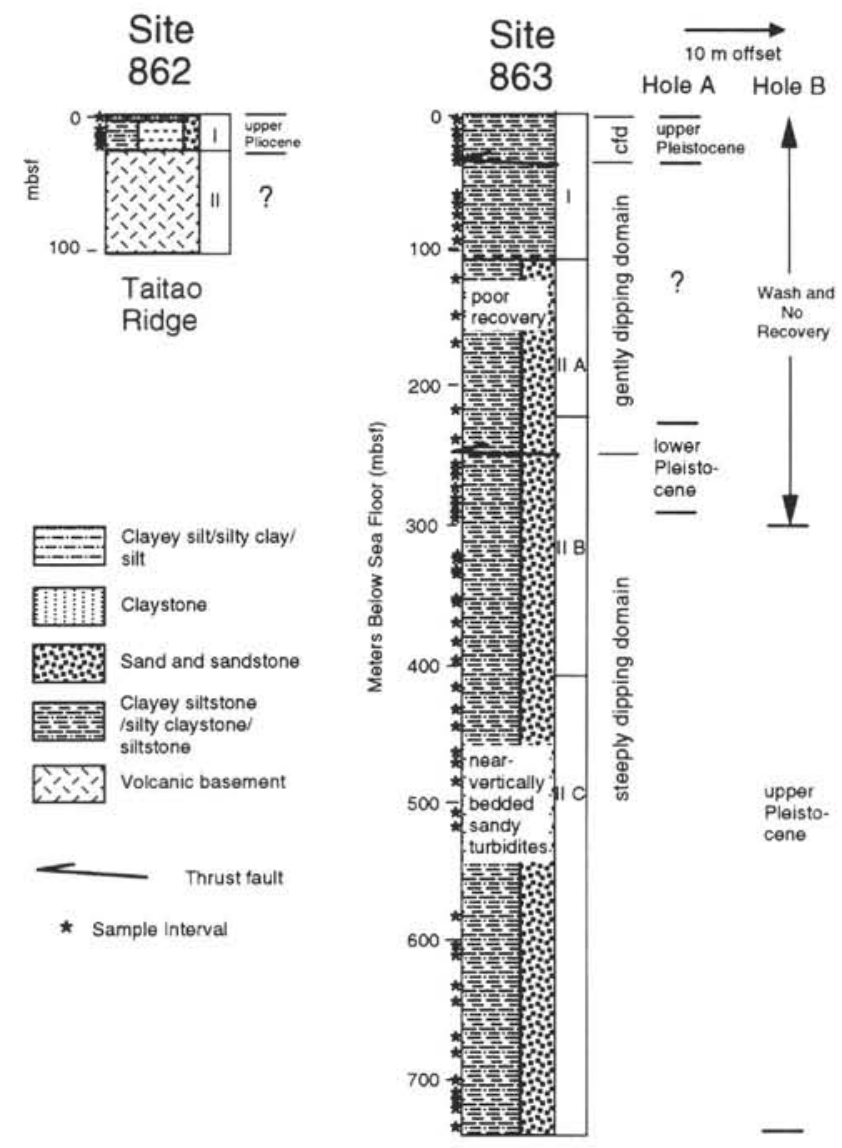

Figure 3. Schematic stratigraphic/structural columns for the southernmost sites drilled on Leg 141 (Fig. 1). The inconsistent stratigraphic ages for Holes 863A and $863 \mathrm{~B}$ suggest that these holes straddle a steeply dipping boundary between upper and lower Pleistocene sediments. For more specific information on the sandy intervals analyzed in this study, see Appendix 1. The shallowest section of Site 863 is a complexly faulted domain (cfd).

opaque minerals, and felsitic fragments with characteristic granular textures, differentiated by the presence of internal relief and potassium or calcium staining (Pls. 1 and 2).

Hypabyssal, fine-grained igneous intrusive fragments and gneissic fragments are represented by aggregates of the following minerals: feldspar, quartz, amphibole, and mica (Pls. 2 and 3). Sand-sized minerals in these fragments were counted as monomineralic constituents, but grains with silt-sized constituents were treated as lithic fragments and placed in the Lma category. Common Lma combinations include: plagioclase and mica; quartz, feldspar, and mica; and quartz, feldspar and pyroxene(?). Based on textural observations in the fine sands at Site 863 , some quartz-feldspar-mica aggregate grains are metaarkose fragments.

A moderately diverse suite of metamorphic fragments is predominantly composed of variably metamorphosed shales, siltstones, and sandstones (Pls. 3 and 4). These include phyllites/slates (Lmp), polycrystalline mica aggregates (Lmm), and quartzose schist fragments with muscovite, biotite, chlorite, and other fine metamorphic minerals $(\mathrm{Lmt})$. These metamorphic fragments are commonly opaque due to the presence of graphite (PI. 3).

Sedimentary lithic fragments are primarily restricted to Hole 863B. These range from claystone/argillite to siltstone, to fragments of very fine sandstone (Pl. 4). The silt component is commonly quartz and plagioclase, with lesser potassium feldspar and opaque minerals. Some are rich in organic matter. Variable induration of these lithics is reflected in differential compaction and the production of pseudomatrix 
(i.e., Dickinson, 1970). Input of reworked sedimentary detritus is also reflected in the presence of reworked Miocene to early Pliocene fauna (Behrmann, Lewis, Musgrave, et al., 1992). Rare sedimentary carbonate and cherty grains were observed.

Care was taken not to disaggregate sedimentary lithic fragments during processing of unconsolidated samples, but most samples from Sites 859,860 , and 861 are poorly sorted muddy sands, which when dried and sieved produce pseudo-sedimentary lithic fragments or "gloms" of matrix. These can be mistaken for sedimentary grains and vice versa, but certain characteristics help differentiate them. Matrix material tends to be more homogeneous and less compacted, and routinely coats grains. Sedimentary lithic textures are best preserved in the impregnated samples from Hole 863B. Larger gloms were routinely inspected to see if they contained sedimentary lithic grains. There is a tendency for lithified samples at Hole $863 \mathrm{~B}$ to be rich in sedimentary lithics and unlithified samples to be poor in sedimentary lithics. Upon review of thin sections from the upper part of this hole and Hole $863 \mathrm{~A}$, this appears to be a true downhole enrichment in sedimentary lithics, rather than an effect of preferential preservation in consolidated units.

Other minor constituents in these samples include siliceous microfauna, such as radiolarians, sponge spicules, and diatoms, and calcareous foraminifers and bioclasts. Rare coarse carbonate crystals may be detrital or may represent incipient cementation.

\section{SAND DETRITAL MODES}

In general, Leg 141 sand detrital modes are uniform. Petrographic analyses show that these sands contain subequal amounts of quartz, feldspar, and lithic components (Fig. 4), with some spread of values towards the lithic-rich and quartz-rich ends of the diagram. The samples generally contain subequal amounts of plagioclase feldspar and quartz and lesser potassium feldspar, with some quartz-rich and plagioclase-rich end members (Fig. 5).

Greater variation is observed in the lithic proportions of Leg 141 samples. Volcanic lithic fragments are present in every sample (Fig. 6 ), and these are predominantly intermediate to mafic, brown and black glassy fragments (Fig. 7). Sands from Site 862 and the lower section of Site 859 are slightly enriched in metamorphic lithics, whereas those from Hole 863B are enriched in sedimentary lithics (Fig. 6; see discussion below).

\section{SAND PROVENANCE}

Leg 141 sand composition reflects the diverse onshore geology of the Chilean forearc (Fig. 8). The low-grade metamorphic component of Leg 141 sands is likely derived from an outer belt of preLate Jurassic metamorphic basement rocks, which include metasediments (metamorphosed cherts, limestones, and turbidites) and metavolcanics (some metamorphosed pillow basalts). These are mostly greenschist-facies rocks that have undergone polyphase deformation and have yielded Paleozoic metamorphic ages (Hervé et al., 1981, 1987, 1988; Forsythe, 1982; Pankhurst et al., 1992).

Another major source province that provides quartzo-feldspathic detritus to the forearc is the Mesozoic to Cenozoic Patagonian batholith (Fig. 8), which is predominantly composed of calcalkaline I-type granites (Forsythe and Prior, 1992). Sources of epiclastic volcanic debris include silicic and intermediate volcanic and volcaniclastic rocks associated with the Patagonian batholith, late Tertiary to Holocene volcanic and volcaniclastic deposits associated with the volcanic arc, specifically Hudson Volcano (Fig. 8) and a Pliocene (3-5 Ma) ophiolite sequence on the Taitao Peninsula (Forsythe and Prior, 1992). The latter volcanic sequence consists of basalt, basaltic andesite, and dacite with lesser rhyodacite and rhyolite (Mpodozis et al., 1985; Forsythe et al., 1986; Kaeding et al., 1990; Forsythe and Prior, 1992). The Taitao Ophiolite is associated with calcalkaline stocks and plutons and may represent an obducted ridge segment or an incipient-forearc-

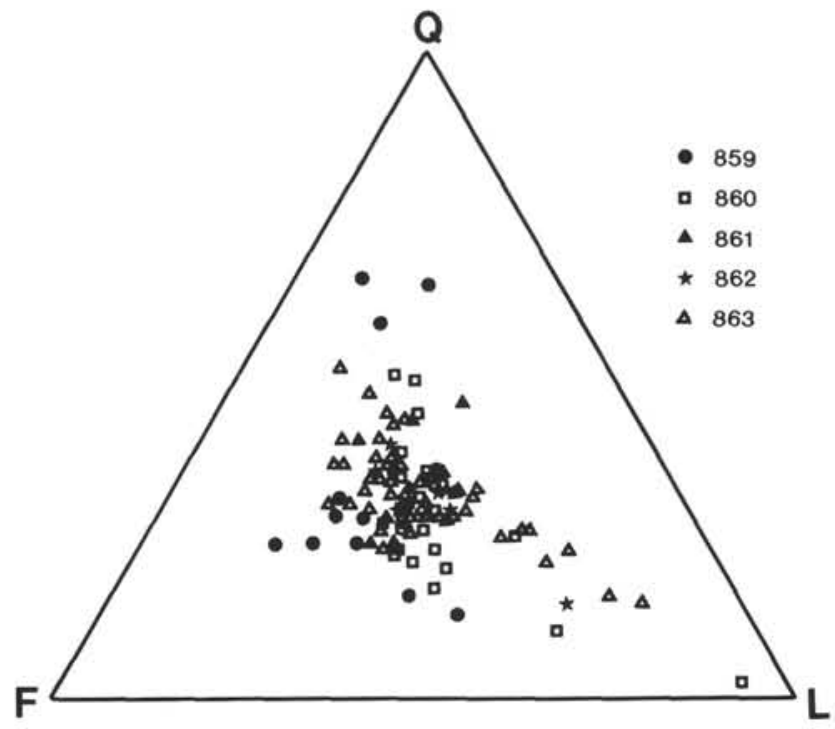

Figure 4. Ternary plot of QFL data by site. See Table I for parameter definitions and formulas and Appendix 2 for recalculated parameters.

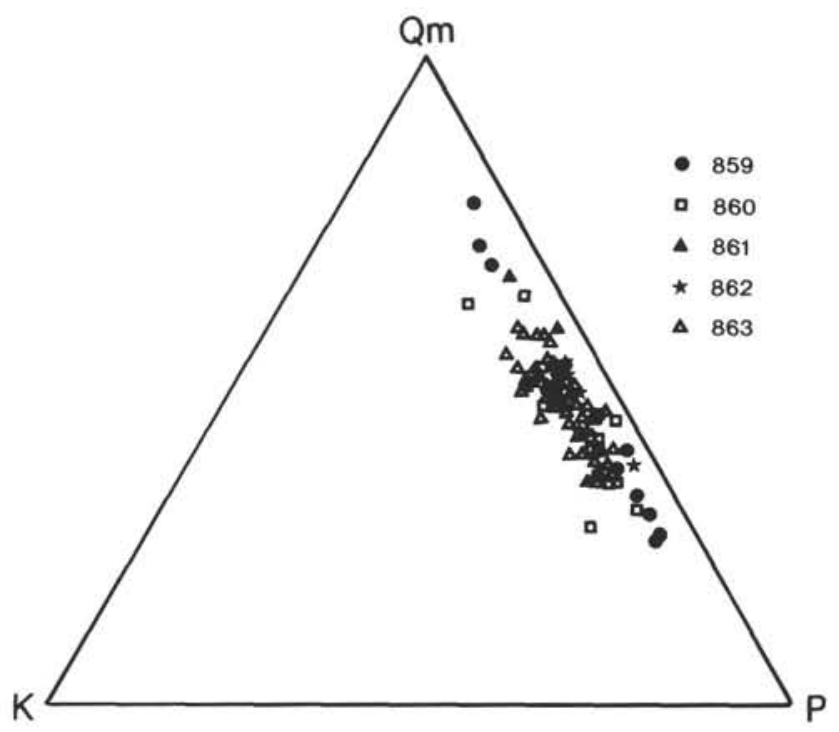

Figure 5. Ternary plot of QmKP data by site. See Table 1 for parameter definitions and formulas and Appendix 2 for recalculated parameters.

rift sequence emplaced in association with ridge-trench interaction (Forsythe and Prior, 1992). Hudson Volcano and forearc volcanic centers on the Taitao Peninsula (Fig. 8) are likely sources of the glassy pyroclastic debris that dominates the lithic component (see further discussion of volcanic sediment provenance below). Detailed chemical analyses of these volcanic fragments are needed to tie them to their source volcanoes.

Exposed sedimentary source rocks include Eocene carbonaceous clastic sequences and Oligocene to Miocene shallow-marine/deltaic sandstone and siltstone (Fig. 8; Servicio Nacional de Geología Y Minería, 1980; DeVries and Stott, 1984; Forsythe et al., 1985; Mpodozis et al., 1985). Other possible sources for sedimentary lithic fragments in Leg 141 samples include the submarine erosion of Pliocene to Pleistocene forearc shelf and slope sediments.

\section{COMPARISON WITH PREVIOUS STUDIES}

Despite the fact that the western margin of South America is considered a classic continental arc-trench system, petrological stud- 


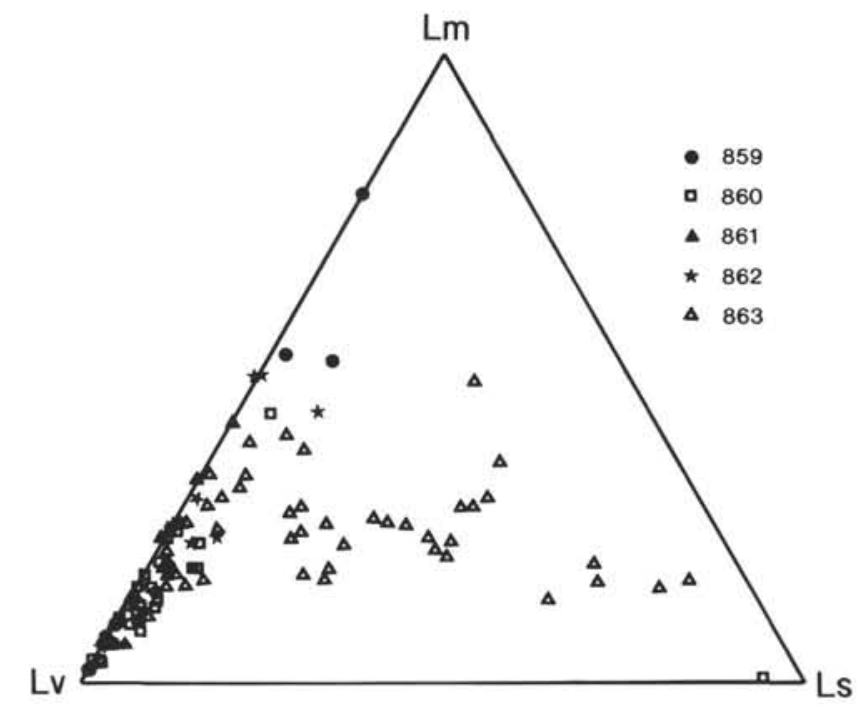

Figure 6. Ternary plot of LmLvLs data by site. See Table 1 for parameter definitions and formulas and Appendix 2 for recalculated parameters.

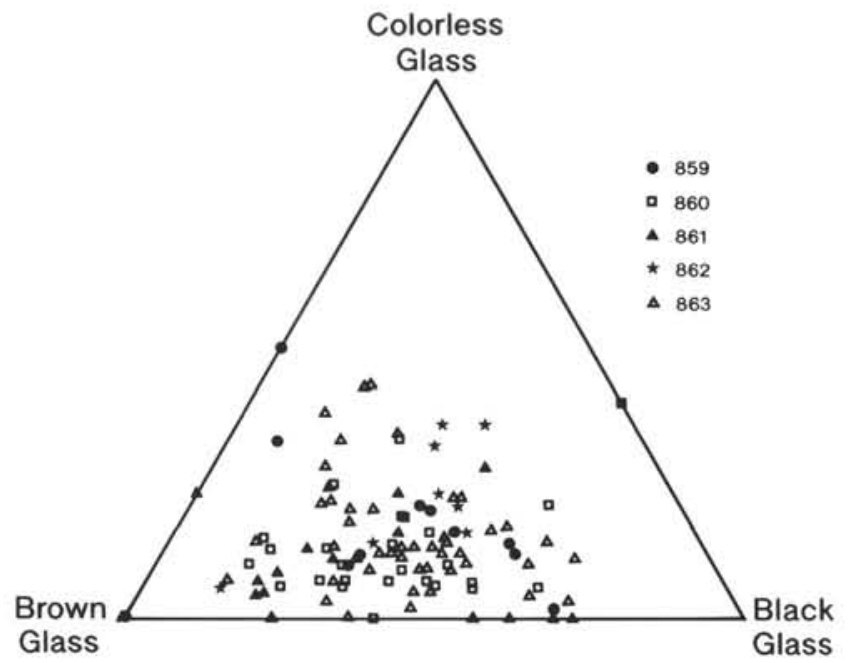

Figure 7. Ternary plot of glassy volcanic lithic proportions, by glass color. See Table 1 for parameter definitions and formulas and Appendix 2 for recalculated parameters.

ies of modern sands derived from this arc system, especially the southern Patagonian arc segment, are limited. In a general study of South American provenance, Potter $(1984,1986)$ analyzed modern beach sands from all the major coastal segments of South America, except the southernmost shoreline of western Patagonia (south of $42^{\circ} \mathrm{S}$ ). Thornburg and Kulm (1987) examined sands from piston cores taken along the Chile Trench $\left(23^{\circ}-42^{\circ} \mathrm{S}\right)$ north of Patagonia. Other global studies of sand provenance include no samples from the western margin of South America (e.g., Dickinson and Suczek, 1979; Ingersoll and Suczek, 1979; Valloni and Maynard, 1981; Valloni and Mezzadri, 1984; Marsaglia and Ingersoll, 1992).

Only Yerino and Maynard (1984) provide data for offshore southern Chile from piston-core samples taken along this margin. They found a latitudinal variation in the proportion of lithic detritus, mainly volcaniclastic debris, which they correlated to arc volcanic activity (Fig. 9); sands derived from inactive segments are lithic-poor, whereas those derived from active segments are lithic-rich. None of their sand samples exhibit metamorphic lithic percentages as high as those seen

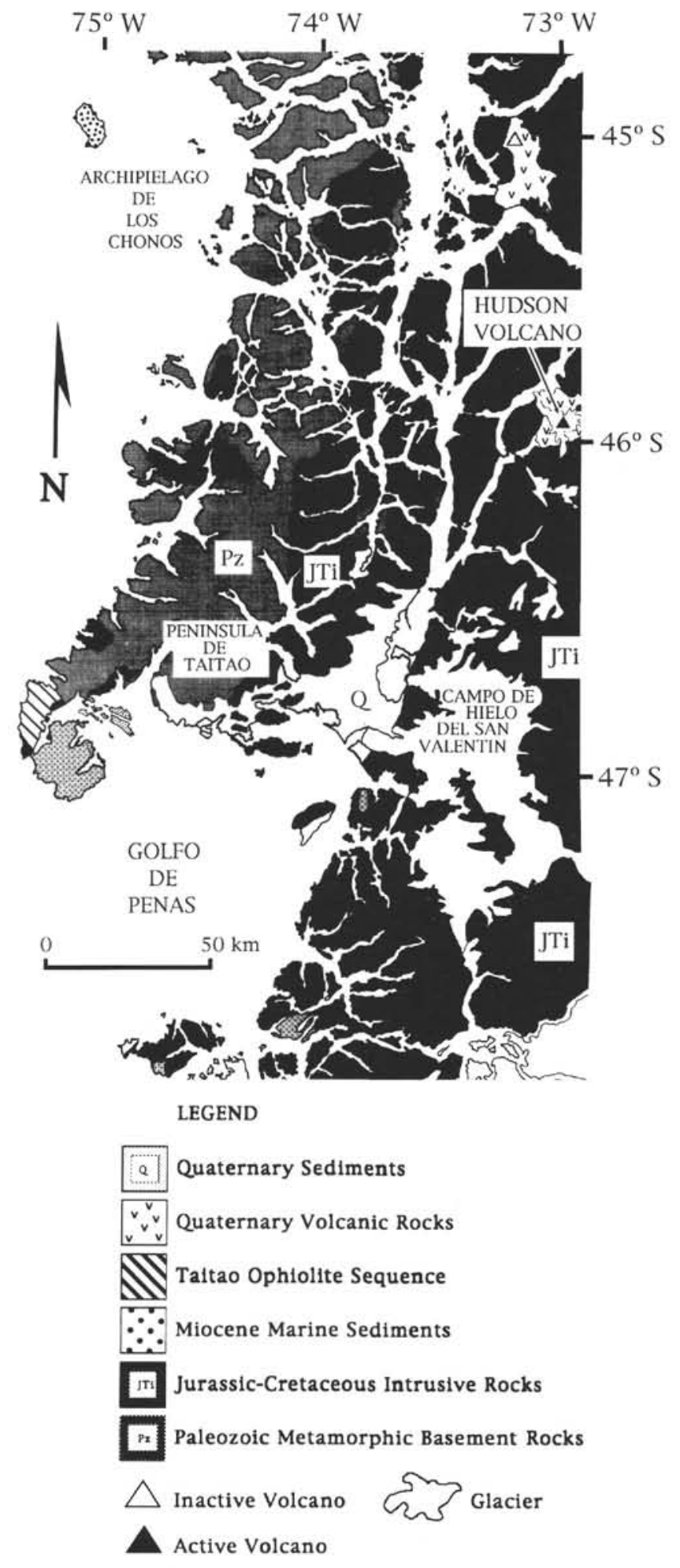

Figure 8. Geologic Map of the Taitao Peninsula region of Chile modified from Servicio Nacional de Geología Y Minería (1980) and Kaeding et al. (1990).

at Sites 862 and 863 . As discussed below, the increase in metamorphic lithics at these sites may be a function of local triple-junction-related uplift of the Taitao Peninsula. The compositional difference in QFL proportions (Fig. 9) between Yerino and Maynard's (1984) pistoncore samples $\left(43^{\circ}-49^{\circ} \mathrm{S}\right)$ and our Leg 141 samples $\left(46^{\circ} \mathrm{S}\right)$ cannot be readily explained by variations in techniques; Yerino and Maynard 
(1984) looked at the very fine to fine sand fractions, stained the thin sections for potassium and calcium feldspar recognition, and collected petrographic data using the Gazzi-Dickinson method. Therefore, this compositional discrepancy remains unresolved.

Leg 141 detrital modes can also be compared to those of other arc-trench systems characterized by Marsaglia and Ingersoll (1992). As shown in Figure 10, Leg 141 samples are most similar to continental arcs with a history of strike-slip along the forearc or arc axis or oblique subduction, and to triple-junction-related sands. This similarity is not surprising for the following reasons: (1) Paleogene convergence along the Chile margin was predominantly oblique (Pilger, 1983; Cande and Leslie, 1986); (2) the modern Chile forearc region is cut by a major arc-parallel, right-lateral, strike-slip fault system, the Liquiñe-Ofqui fault zone (Forsythe and Prior, 1992); and (3) at least four periods of uplift and erosion have been documented in Tertiary sections within the Golfo de Penas region associated with migration of the Chile Triple Junction (Forsythe et al., 1985).

\section{DISCUSSION}

\section{Slope Transect Sites}

There is a distinct change in lithic proportions down section at Site 859 . This break occurs between 284 and $420 \mathrm{~m}$, below the change from flat-bedded to broken formation (Fig. 2; see Site 859 site report in Behrmann, Lewis, Musgrave, et al., 1992). At $420 \mathrm{~m}$ the dominant lithics are metamorphic fragments, and the quartz content increases. This can be seen in the bimodal distribution of Site 859 lithic compositions on Figure 10 ( $859 \mathrm{U}$, upper section, and 859L, lower section). Although the depth at which this apparent change in provenance occurs is poorly constrained because of the paucity of sand in this lower interval, it is significant, and may correspond to a major structural break within the broken formation. No similar trend is observed at Sites 860 and 861 , where sand compositions remain relatively uniform. One explanation for this discrepancy is that the sediments cored at Sites 860 and 861 and in the upper part of Site 859 are slope deposits with a similar onshore source of sediment. The lowermost section at Site 859 could then represent offscraped trench fill or trench overspill derived from along-strike submarine canyons, hence the anomalous composition. The quartzose nature of these sediments would be consistent with an uplifted metamorphic source, possibly the northern Taitao Peninsula. Alternatively, the quartz and metamorphic enrichment could be a diagenetic effect resulting from dissolution of plagioclase feldspar and volcanic lithic fragments. In support of this theory, the lower interval is characterized by common alteration of volcanic lithics, birefringent clay-mineral coatings on grains, inorganic microcrystalline carbonate, and an increase in chlorite and decrease in smectite in the clay-mineral fraction (see Site 859 site report in Behrmann, Lewis, Musgrave, et al., 1992). The anomalously high consolidation of the sediments at Site 859 suggests that some removal of section may have occurred at this site, and maximum burial depths may have been much greater (Behrmann, Lewis, Musgrave, et al., 1992).

\section{Site 862}

The sandy sediment examined from Site 862 on the Taitao Ridge is relatively uniform in composition, and similar to that of the other Leg 141 sites (Figs. 4 and 5), but with an overall higher metamorphic content (Fig. 6). This sediment was deposited during the late Pliocene (NN18-16), near present water depths, but prior to Chile Ridge subduction in this region.

At present, the Taitao ridge forms a spur off the continental shelf near the Taitao Peninsula (Fig. 1); the similarity of its sediment composition with that of other Leg 141 sites suggests that the Taitao Ridge was connected to the shelf during the late Pliocene and could not have been an isolated ridge on the subducting plate. The presence of 10 locally derived, hydroclastic vitric-tuff layers intercalated with

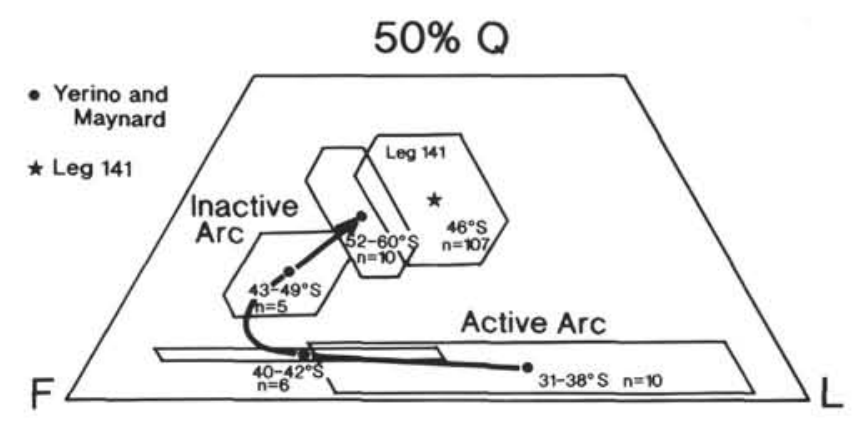

Figure 9. QFL ternary diagram comparing the mean Leg 141 sand composition with detrital modes calculated from data collected by Yerino and Maynard (1984). Polygons represent the fields of variation (standard deviations) about mean values (filled stars and circles). Yerino and Maynard data are grouped according to latitude of sample locations.

these mainland-derived sediments (see Strand, this volume) suggests that ridge volcanism was concurrent with sediment transport from the mainland. Triple-junction-related uplift and erosion of metamorphic basement rocks on the Taitao Peninsula (Fig. 8) may account for the higher metamorphic component in Site 862 sands, but there is no distinct evidence of Taitao Ophiolite-derived material at this site. Given present offshore bathymetry (Fig. 1), however, material eroded from the Taitao Ophiolite (Fig. 8) would likely be carried off the shelf edge south of the Taitao Ridge rather than northward toward Leg 141 sites.

\section{Site 863}

The composition of sub-vertically bedded, anomalously lithified (see Prior et al., this volume) Pleistocene units at Site 863 reflects tectonism and perhaps the effects of glaciation in their source areas. The sedimentary lithic fragments that characterize the turbidite sandstones of Hole 863B may have been produced by rapid downcutting in the unnamed canyon which heads off the continental shelf north of the Taitao Peninsula (Fig. 1). During Pleistocene glaciation, this channel may have funneled sediment-laden glacial meltwaters from the Taitao Peninsula into the Chile trench, and the resulting sequence of sandy turbidites was subsequently upended in response to recent subduction of the Chile Rise. Thus, Hole 863B sedimentary lithic grains may be eroded accretionary-prism sediments or till pellets, or possibly, they represent the eroded sedimentary cover of the nowdenuded Taitao Peninsula.

Input of sedimentary lithic fragments into trench sequences is known from the Japan triple-junction region, where the Fuji River drains uplifted accretionary-prism sediments and the crosscutting volcanic edifices of the magmatic arc (Marsaglia et al., 1991, 1992). Similar sedimentary-lithic-rich sequences have been cored in the Japan forearc and are thought to have been associated with an Oligocene forearc disturbance, possibly related to the passage of a triple junction (Marsaglia et al., 1991, 1992).

\section{Controls on Sediment Provenance in the Southern Chile Forearc Region}

The three main controls on sand provenance near the Chile Triple Junction are tectonics, climate, and volcanism. These controls are, in part, interrelated.

\section{Tectonics}

As summarized by Behrmann, Lewis, Musgrave, et al. (1992), ridge subduction in a triple-junction setting stratigraphically and structurally affects the overriding plate. Certain effects are particularly 
A

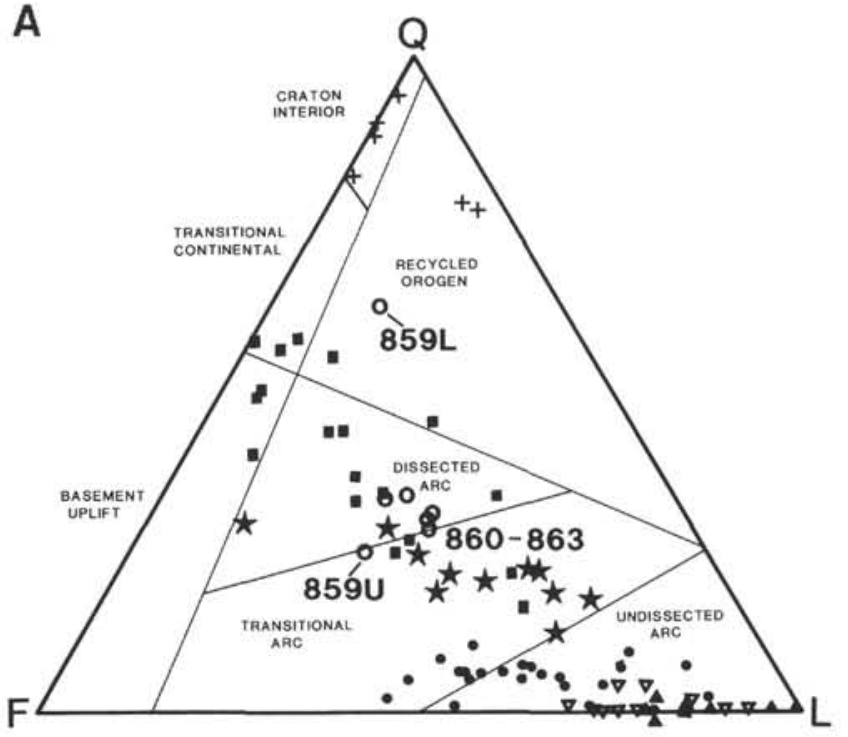

B

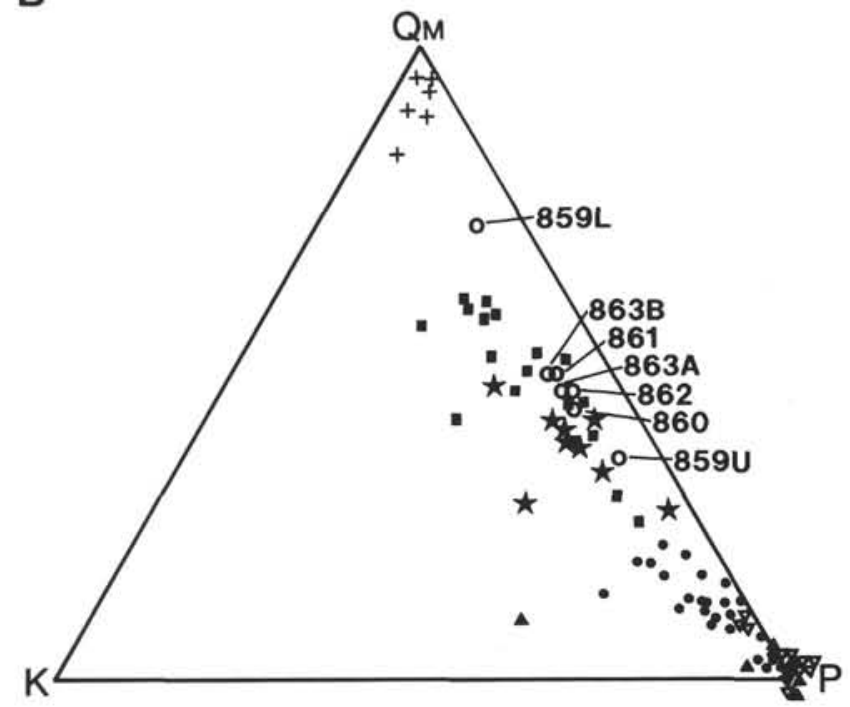

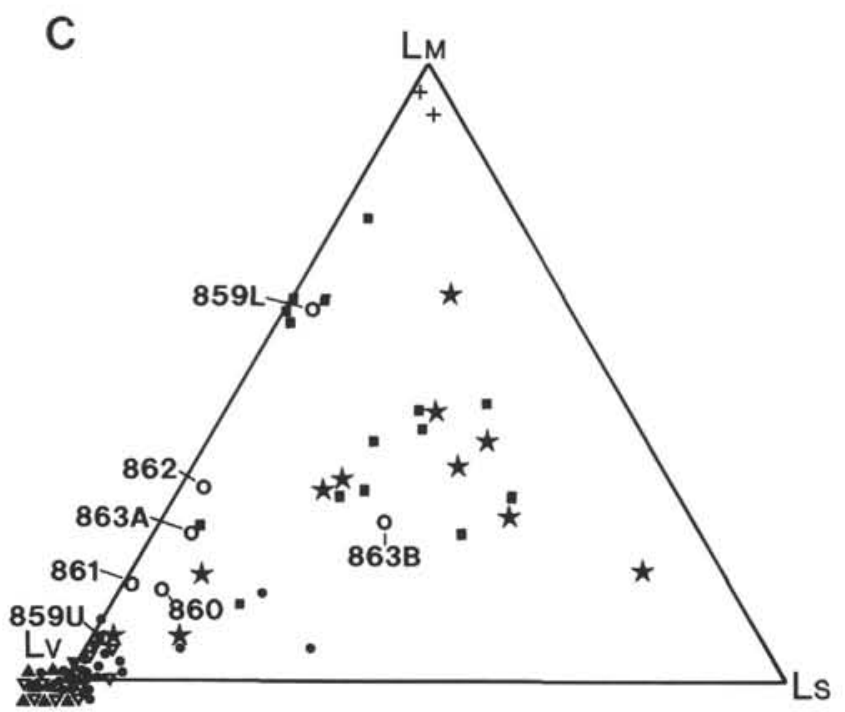

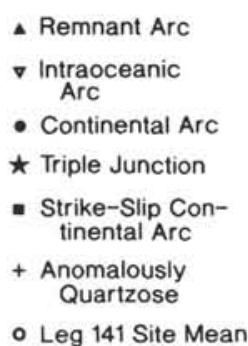

Figure 10. Ternary plots (A, B, and C) with fields based on Dickinson et al. (1983). Symbols correspond to mean compositions of sand and sandstone from arc-related DSDP sites (Marsaglia and Ingersoll, 1992) and from ODP Leg 141 sites. Data for Site 859 subdivided into a lower altered? sequence (859L; $420-469$ mbsf) and an upper sequence ( $859 \mathrm{U} ; 12-284 \mathrm{mbsf}$ ), and data for Site 863 subdivided by hole (for Holes $863 \mathrm{~A}$ and $863 \mathrm{~B}$ ).

pertinent to sand-provenance studies (Marsaglia et al., 1991, 1992; Marsaglia and Ingersoll, 1992); for example, the passage of a triple junction may be recorded along the arc by rapid uplift and subsidence associated with a lull in arc magmatism, and recorded in the forearc by anomalous near-trench magmatism, uplift, subsidence and extensional deformation (DeLong and Fox, 1978; Marshak and Karig, 1977; DeLong et al., 1978, 1979; Herron et al., 1981; Barker, 1982). The Taitao Ophiolite was rapidly uplifted and exhumed during the late Pliocene or Pleistocene due to migration of the Chile Triple Junction (Forsythe and Prior, 1992).

Sedimentary patterns in forearc settings are commonly disrupted inboard of triple junctions. Triple-junction tectonics may serve to localize the formation of submarine canyons that control the rate of influx and provenance of sediment deposited in the trench. Large submarine canyons flank the Izu Peninsula near the Japan Triple Junction (see Marsaglia et al., 1991, 1992, and Marsaglia and Ingersoll, 1992), and similar submarine canyons occur in the vicinity of the Taitao Ridge (Fig. 1).

\section{Climate}

Glaciation has characterized the Patagonian Andes since at least 4.6 Ma, with significant ice-field expansion between 2.4 and $1.2 \mathrm{Ma}$ (Mercer, 1976; Rabassa and Clapperton, 1990). South of latitude $43^{\circ} \mathrm{S}$, during the greatest extent of glaciation in the early Pleistocene (1.2 Ma; Mercer, 1976), glaciers extended from the Andean continental divide out across the Pacific continental shelf (Clapperton, 1990; Rabassa and Clapperton, 1990). The Taitao Peninsula approximately marks the northern limit of continental glaciation during the Pliocene/Pleistocene, the last vestige of which is the Northern Patagonia icefield (Campo de Hielo del San Valentin; Fig. 8).

The preferential glaciation of the southern Patagonian Andes may be a function of differential uplift induced by migration of the Chile Triple Junction; at present, there is a 2 to $3 \mathrm{~km}$ increase in elevation of the Patagonian Andes south from the Taitao Peninsula (Forsythe and Prior, 1992). Extreme differences in trench sedimentation patterns north and south of the triple junction may be a function of the 
Pliocene limit of continental glaciation at this latitude (Lothian, pers. comm., 1993).

\section{Volcanism}

The modern volcanic arc in southern Chile is superposed on the Patagonian batholith trend. Presently, there is a volcanic gap of approximately $300 \mathrm{~km}$ in the Chilean Arc from Lautaro Volcano at $49^{\circ} \mathrm{S}$ to Hudson Volcano at $46^{\circ} \mathrm{S}$ (Fig. 8), which may have evolved over a subducted "slab window" (Forsythe and Nelson, 1985; Cande and Leslie, 1986; Forsythe and Prior, 1992). Recent eruptions of Hudson Volcano have probably provided little volcaniclastic material to the trench slope. The ash clouds produced during these eruptions are carried by the prevailing "Roaring Forties" winds to the east (anonymous, 1991). Westward transport of material is limited to material carried down valleys into fiords and an intricate series of interior waterways that characterize the Chonos Archipelago (see Fig. 8; Best, 1992). During glacial maxima, volcaniclastic material may have been carried as englacial or supraglacial debris from the arc to the forearc shelf region.

\section{SUMMARY AND CONCLUSIONS}

Leg 141 sand compositions are fairly uniform and these sediments have a dissected-arc provenance, reflecting extensive onshore erosion of quartzose Paleozoic metasedimentary basement rocks and the Mesozoic Patagonian batholith. The lithic component is dominantly intermediate to mafic volcaniclastic debris derived from arc volcanoes, and perhaps, near-trench volcanic centers on the Taitao Peninsula. Sites south of the Chile Triple Junction show higher metamorphic and sedimentary lithic proportions, probably due to uplift and erosion in the Taitao Peninsula region during northward migration of the triple junction.

Thus, the three main controls on sand provenance in the Chile forearc region at latitude $46^{\circ} \mathrm{S}$ are tectonics, volcanism, and climate. Tectonic uplift of the forearc due to triple junction migration, and tectonic uplift of the arc system as a whole due to oblique subduction and arc-parallel strike-slip faulting have resulted in the erosion of metasedimentary Paleozoic arc basement rocks and the Patagonian batholith. Late Cenozoic glaciation in this region may have been enhanced by this uplift and provided a means of supplying arc volcaniclastics (and volcaniclastics from Taitao volcanic centers?) to the forearc.

Intersite and intrasite trends in sand provenance are limited to higher quartz and metamorphic contents at the bottom of Site 859 and higher metamorphic and sedimentary lithic contents at Sites 862 and 863 . The former trend is most likely a function of diagenetic modification by dissolution of plagioclase and volcanic lithic fragments, and the latter trend likely reflects tectonism in the Taitao Peninsula region associated with triple-junction migration.

\section{ACKNOWLEDGMENTS}

This project was supported by a grant from the National Science Foundation and Joint Oceanographic Institutions administered by the Texas A\&M Research Foundation. Additional student support came from a Research Careers for Minority Students Program funded by the National Science Foundation, and MUTEC stipends from the U.S. Department of Energy. This study also benefited from equipment purchased with funds from an NSF-ILI grant (\#9152183). We thank Kathleen Devaney, Raymond Ingersoll, and Kevin Pickering for their thoughtful reviews of the manuscript, and J.B. Maynard for providing petrographic data for Peru-Chile Trench samples.

\section{REFERENCES}

Anonymous, 1991. Major eruption reported in Chile. Eos, 393-394.

Bangs, N., Cande, S.C., Lewis, S.D., and Miller, J., 1992. Structural framework of the Chile Margin at the Chile Ridge collision zone. In Behrmann, J.H., Lewis, S.D., Musgrave, R.J., et al., Proc. ODP, Init. Repts., 141: College Station, TX (Ocean Drilling Program), 11-21.

Barker, P.F., 1982. The Cenozoic subduction history of the Pacific margin of the Antarctic Peninsula: ridge crest-trench interactions. J. Geol. Soc. London, 139:787-801.

Behrmann, J.H., Lewis, S.D., Musgrave, R.J., et al., 1992. Proc. ODP, Init. Repts., 141: College Station, TX (Ocean Drilling Program).

Best, J.L., 1992. Sedimentology and event timing of a catastrophic volcaniclastic mass flow, Volcan Hudson, Southern Chile. Bull. Volcanol., $54: 299-318$

Cande, S.C., Herron, E.M., and Hall, B.R., 1982. The early Cenozoic tectonic history of the southeast Pacific. Earth Planet. Sci. Lett., 57:63-74.

Cande, S.C., and Leslie, R.B., 1986. Late Cenozoic tectonics of the southern Chile Trench. J. Geophys. Res., 91:471-496.

Cande, S.C., Leslie, R.B., Parra, J.C., and Hobart, M., 1987. Interaction between the Chile Ridge and Chile Trench: geophysical and geothermal evidence. J. Geophys. Res., 92:495-520.

Clapperton, C.M., 1990. Quaternary glaciations in the Southern hemisphere: an overview. Quat. Sci. Rev., 9:299-304.

DeLong, S., and Fox, P., 1978. Geological consequences of ridge subduction. In Talwani, M., and Pitman, W.C., II (Eds.), Island Arcs, Deep Sea Trenches, and Back-arc Basins. Am. Geophys. Union, Maurice Ewing Ser., 1:221-228.

DeLong, S.E., Fox, P.J., and McDowell, F.W., 1978. Subduction of the Kula Ridge at the Aleutian Trench. Geol. Soc. Am. Bull., 89:83-95.

DeLong, S.E., Schwarz, W.M., and Anderson, R.N., 1979. Thermal effects of ridge subduction. Earth Planet. Sci. Lett., 44:239-246.

DeVries, T.J., Stott, L.D., and Zinsmeister, W.J., 1984. Neogene fossiliferous deposits in Southern Chile. Antarct. J. U.S., 19:12-13.

Dickinson, W.R., 1970. Interpreting detrital modes of graywacke and arkose. J. Sediment. Petrol., 40:695-707.

Dickinson, W.R., and Suczek, C.A., 1979. Plate tectonics and sandstone compositions. AAPG Bull., 63:2164-2182.

Dickinson, W.R., Beard, L.S., Brakenridge, G.R., Erjavec, J.L., Ferguson, R.C., Inman, K.F., Knepp, R.A.. Lindberg, F.A., and Ryberg, P.T., 1983. Provenance of North American Phanerozoic sandstones in relation to tectonic setting. Geol. Soc. Am. Bull., 94:222-235.

Forsythe, R., and Prior, D., 1992. Cenozoic continental geology of South America and its relations to the evolution of the Chile Triple Junction. In Behrmann, J.H., Lewis, S.D., Musgrave, R.J., et al., Proc. ODP, Init. Repts., 141: College Station, TX (Ocean Drilling Program), 23-31.

Forsythe, R.D., 1982. The late Paleozoic to early Mesozoic evolution of southern South America: a plate tectonic interpretation. J. Geol. Soc. London, 139:671-682.

Forsythe, R.D., and Nelson, E., 1985. Geological manifestations of ridge collision: evidence from the Golfo de Penas-Taitao Basin, southern Chile. Tectonics, 4:477-495.

Forsythe, R.D., Nelson, E.P., Carr, M.J., Kaeding, M.E., Herve, M., Mpodozis, C., Soffia, J.M., and Harambour, S., 1986. Pliocene near-trench magmatism in southern Chile: a possible manifestation of ridge collision. Geology, 14:23-27.

Forsythe, R.D., Olsson, R.K., Johnson, C., and Nelson, E.P., 1985. Stratigraphic and micropaleontologic observations from the Golfo de Penas-Taitao Basin, southern Chile. Rev. Geol. Chile, 25/26:3-12.

Herron, E.M., Cande, S.C., and Hall, B.R., 1981. An active spreading center collides with a subduction zone: a geophysical survey of the Chile margin triple junction. Mem.-Geol. Soc. Am., 154:683-701.

Hervé, F., Godoy, E., Garrido, I., Hormazabal, L., Brook, M., Pankhurst, R.J., and Vogel, S., 1988. Geocronologia y condiciones de metamorfismo del

\footnotetext{
- Abbreviations for names of organizations and publications in ODP reference lists follow the style given in Chemical Abstracts Service Source Index (published by American Chemical Society).
} 
complejo de subduccion del Archipelago de los Chonos. Act. Congr: Geol. Chileno, 5:E157-173.

Hervé, F., Godoy, E., Parada, M., Ramos, V., Rapela, C., Mpodozis, C., and Davidson, J., 1987. A general view of the Chilean-Argentine Andes, with emphasis on their early history. Am. Geophys. Union Geodyn. Ser., 18:97113.

Hervé, F., Mpodozis, M., Davidson, J., and Godoy, E., 1981. Observaciones estructurales y petrograficas en el basamento metamorfico del Archipelago de los Chonos entre el Canal King y el Canal Ninualac, Aisen. Rev. Geol. Chile, 13/14:3-16.

Ingersoll, R.V., Bullard, T.F., Ford, R.L., Grimm, J.P., Pickle, J.D., and Sares, S.W., 1984. The effect of grain size on detrital modes: a test of the Gazzi-Dickinson point-counting method. J. Sediment. Petrol., 54:103116.

Ingersoll, R.V., and Suczek, C.A., 1979. Petrology and provenance of Neogene sand from Nicobar and Bengal Fans, DSDP Sites 211 and 218. J. Sediment. Petrol., 49:1217-1228.

Kaeding, M., Forsythe, R.D., and Nelson, E.P., 1990. Geochemistry of the Taitao ophiolite and near-trench intrusions from the Chile Margin Triple Junction. J. S. Am. Earth Sci., 3:161-177.

Leslie, R.B., 1986. Cenozoic tectonics of southern Chile: triple junction migration, ridge subduction, and forearc evolution [Ph.D. thesis]. Columbia Univ., New York, NY.

Marsaglia, K.M., 1991. Provenance of sands and sandstones from a rifted continental arc, Gulf of California, Mexico. In Fisher, R.V., and Smith, G.A. (Eds.), Sedimentation in Volcanic Settings. Soc. Econ. Paleontol. Mineral. Spec. Publ., 45:237-248.

, 1992. Petrography and provenance of volcaniclastic sands recovered from the Izu-Bonin Arc, Leg 126. In Taylor, B., Fujioka, K., et al., Proc. ODP, Sci. Results, 126: College Station, TX (Ocean Drilling Program), 139-154.

Marsaglia, K.M., and Ingersoll, R.V., 1992. A reassessment of magmatic-arc provenance: compositional trends in arc-related, deep-marine sand and sandstone. Geol. Soc. Am. Bull., 104:1637-1649.

Marsaglia, K.M., Ingersoll, R.V. and Gergen, L.D., 1991. Arc-related, triplejunction provenance of sand and sandstone. SEPM 1991 Theme Meeting, Portland, 20. (Abstract)

Marsaglia, K.M., Ingersoll, R.V., and Packer, B.M., 1992. Tectonic evolution of the Japanese Islands as reflected in modal compositions of Cenozoic forearc and backarc sand and sandstone. Tectonics, 11:1028-1044.

Marsaglia, K.M., and Tazaki, K., 1992. Diagenetic trends in Leg 126 sandstones. In Taylor, B., Fujioka, K., et al., Proc. ODP, Sci. Results, 126 College Station, TX (Ocean Drilling Program), 125-138.
Marshak, R.S., and Karig, D.E., 1977. Triple junctions as a cause for anomalously near-trench igneous activity between the trench and the volcanic arc. Geology, 5:233-236.

Mercer, J.H., 1976. Glacial history of southernmost South America. Quat. Res., 6:125-166.

Mpodozis, C., Hervé, M., Nasi, C., Forsythe, R.D., and Nelson, E.P., 1985. El magmatismo Plioceno de Peninsula Tres Montes, y su relacion con la evolution del Punto Triple de Chile Austral. Rev. Geol. Chile, 25/26:13-28.

Pankhurst, R.J., Hervé, F., Rojas, L., and Cembrano, J., 1992. Magmatism and tectonics in continental Chiloe, Chile $\left(42^{\circ}-42^{\circ} 30 \mathrm{~S}\right)$. Tectonophysics, 205:283-294.

Pilger, R.H., Jr., 1978. A method for finite plate reconstructions, with applications to Pacific-Nazca plate evolution. Geophys. Res. Lett., 5:469-472.

1983. Kinematics of the South American subduction zone from global plate reconstructions. Am. Geophys. Union Geodyn. Ser., 9:113126.

Potter, P.E., 1984. South American modern beach sands and plate tectonics. Nature, 311:645-648.

, 1986. South America and a few grains of sand. Part 1: beach sands. J. Geol., 94:301-319.

Rabassa, J., and Clapperton, C.M., 1990. Quaternary glaciations of the southern Andes. Quat. Sci. Rev., 9:153-174.

Servicio Nacional de Geologia Y Mineria, 1980. Geological map of Chile. Inst. Investig. Geol., Inscr. 52527 (scale 1:1,000,000).

Shipboard Scientific Party, 1992. Geological background and objectives. In Behrmann, J.H., Lewis, S.D., Musgrave, R.J., et al., Proc. ODP, Init. Repts., 141: College Station, TX (Ocean Drilling Program), 5-9.

Thornburg, T.M., and Kulm, L.D., 1987. Sedimentation in the Chile Trench: petrofacies and provenance. J. Sediment. Petrol., 57:55-74.

Valloni, R., and Maynard, J.B., 1981. Detrital modes of recent deep-sea sands and their relation to tectonic setting: a first approximation. Sedimentology, $28: 75-83$

Valloni, R., and Mezzadri, G., 1984. Compositional suites of terrigenous deep-sea sands of the present continental margins. Sedimentology, 31:353364.

Yerino, L.N., and Maynard, J.B., 1984. Petrography of modern sands from the Peru-Chile Trench and adjacent areas. Sedimentology, 31:83-89.

Date of initial receipt: 13 July 1993

Date of acceptance: 4 March 1994

Ms 141SR-005 


\section{APPENDIX 1}

Raw Data

\begin{tabular}{|c|c|c|c|c|c|c|c|c|c|c|c|c|c|c|c|c|c|c|c|c|c|}
\hline $\begin{array}{l}\text { Core, section, } \\
\text { interval }(\mathrm{cm})\end{array}$ & $\begin{array}{l}\text { Depth } \\
\text { (mbsf) }\end{array}$ & $\begin{array}{l}\text { Grain } \\
\text { size }\end{array}$ & $\begin{array}{c}\text { Age } \\
\text { (nannofossil } \\
\text { zone) }\end{array}$ & Qp & Qm & $P$ & $\begin{array}{c}\mathrm{P} \\
\mathrm{A} / \mathrm{D}\end{array}$ & K & $\begin{array}{l}\text { Unst } \\
\text { Feld }\end{array}$ & Lvo & $\begin{array}{l}\text { Lvv } \\
\text { Brgl }\end{array}$ & $\begin{array}{l}\text { Lvv } \\
\text { Orgl }\end{array}$ & $\begin{array}{l}\text { Lvv } \\
\text { Clgl }\end{array}$ & $\begin{array}{l}\text { Lvv } \\
\text { Blgl }\end{array}$ & $\begin{array}{l}\text { LvV } \\
\text { A/D }\end{array}$ & Lvf & $\begin{array}{c}\text { Lvml } \\
\text { Brgl }\end{array}$ & $\begin{array}{l}\text { Lvml } \\
\mathrm{Clgl}\end{array}$ & $\begin{array}{l}\text { Lvml } \\
\text { Blgl }\end{array}$ & $\begin{array}{c}\text { Lvml } \\
\mathrm{A} / \mathrm{D}\end{array}$ & $\begin{array}{c}\text { Lvml } \\
\text { Brgl }\end{array}$ \\
\hline \multicolumn{22}{|l|}{$141-859 \mathrm{~A}-$} \\
\hline $3 \mathrm{H}-2,24-25$ & 12.4 & 1 & $18-16$ & 1 & 56 & 145 & 0 & 11 & 3 & 1 & 26 & 0 & 11 & 3 & 6 & 3 & 38 & 4 & 36 & 4 & 6 \\
\hline $3 \mathrm{H}-3,115-116$ & 14.85 & 1 & $18-16$ & 1 & 49 & 137 & 0 & 12 & 1 & 0 & 30 & 1 & 4 & 31 & 1 & 3 & 18 & 0 & 79 & 1 & 4 \\
\hline $6 \mathrm{X}-1,96-98$ & 35.65 & 1 & $18-16$ & i & 104 & 155 & 0 & 8 & 2 & 0 & 21 & 0 & 17 & 10 & 6 & 2 & 14 & 1 & 22 & 1 & 2 \\
\hline \multicolumn{22}{|l|}{$141-859 \mathrm{~B}-$} \\
\hline $2 R-4,1-5$ & 66.1 & 1 & $18-16$ & 3 & 119 & 97 & 0 & 12 & 0 & 0 & 22 & 0 & 19 & 12 & 0 & 1 & 22 & 3 & 25 & 0 & 1 \\
\hline $16 \mathrm{R}-3,146-149$ & 259.05 & 1 & $18-16$ & 5 & 78 & 149 & 0 & 13 & 2 & 6 & 10 & 0 & 5 & 4 & 3 & 5 & 37 & 3 & 13 & 0 & 0 \\
\hline $17 \mathrm{R}-1,32-34$ & 264.6 & 1 & $18-16$ & 2 & 96 & 157 & 0 & 15 & 0 & 4 & 5 & 0 & 0 & 10 & 3 & 11 & 13 & 8 & 21 & 1 & 0 \\
\hline $17 R-4,74-76$ & 269.55 & i & $18-16$ & 7 & 104 & 145 & 0 & 18 & 1 & i & 7 & 1 & 5 & 7 & 5 & 7 & 8 & 1 & 20 & 2 & i \\
\hline $19 R-1,79-81$ & 284.3 & $\mathrm{i}$ & $18-16$ & 0 & 74 & 168 & 0 & 13 & 0 & 0 & 2 & 0 & 3 & 6 & 11 & 7 & 10 & 2 & 8 & 3 & 0 \\
\hline $33 R-2,61-63$ & 420.44 & 1 & $18-16$ & 2 & 250 & 79 & 0 & 24 & 0 & 0 & 0 & 0 & 0 & 0 & 9 & 2 & 1 & 0 & 0 & 2 & 0 \\
\hline 37R-CC, 5-9 & 459.1 & 1 & $18-16$ & 6 & 104 & 24 & 0 & 6 & 0 & 0 & 1 & 0 & 1 & 0 & 1 & 0 & 0 & 1 & 0 & 1 & 1 \\
\hline $38 \mathrm{R}-\mathrm{CC}, 8-10$ & 468.9 & $i$ & $18-16$ & 4 & 214 & 79 & 0 & 23 & 0 & 0 & 2 & 0 & 0 & 0 & 5 & 4 & 5 & 4 & 0 & 5 & 0 \\
\hline $\begin{array}{l}141-860 \mathrm{~A}- \\
1 \mathrm{H}-\mathrm{CC}, 2-3\end{array}$ & 9.5 & 1 & $21-20$ & 4 & 97 & 122 & 0 & 15 & 1 & 1 & 32 & 0 & 7 & 14 & 7 & 6 & 14 & 1 & 22 & 0 & 1 \\
\hline \multicolumn{22}{|l|}{ 141-860B- } \\
\hline $2 \mathrm{H}-6,110-112$ & 9 & 2 & $21-20$ & 3 & 125 & 109 & 0 & 23 & 2 & 0 & 19 & 0 & 0 & 12 & 2 & 12 & 23 & 0 & 17 & 0 & 4 \\
\hline $3 \mathrm{H}-4,139-142$ & 16.75 & 1 & 20 & 3 & 129 & 99 & 0 & 21 & 0 & 0 & 13 & 0 & 3 & 7 & 1 & 5 & 22 & 1 & 18 & 0 & 1 \\
\hline $3 \mathrm{H}-7,30-35$ & 20.2 & i & 20 & 4 & 115 & 91 & 0 & 22 & 0 & 0 & 30 & 0 & 8 & 8 & 6 & 2 & 20 & 1 & 16 & 0 & i \\
\hline $4 \mathrm{H}-2,140-143$ & 23.3 & 1 & 19 & 9 & 104 & 89 & 0 & 13 & 1 & 1 & 20 & 0 & 4 & 7 & 2 & 2 & 21 & $i$ & 32 & 0 & 0 \\
\hline $5 \mathrm{H}-5,113-116$ & 37.05 & 1 & 19 & 3 & 113 & 105 & 0 & 28 & 0 & 0 & 37 & 1 & 10 & 7 & 2 & 1 & 21 & 2 & 17 & 0 & 2 \\
\hline $5 \mathrm{H}-7,35-40$ & 38.65 & $i$ & 19 & 4 & 118 & 104 & 0 & 15 & 0 & 4 & 35 & 0 & 11 & 9 & 4 & 1 & 29 & 2 & 8 & 2 & 5 \\
\hline 5H-CC, $141-144$ & 39.4 & 1 & 19 & 7 & 119 & 102 & 0 & 16 & 0 & 0 & 40 & 0 & 4 & 9 & 4 & 4 & 20 & 2 & 18 & 2 & 1 \\
\hline $6 \mathrm{H}-3,76-79$ & 43.15 & 2 & 19 & 0 & 71 & 119 & 0 & 14 & 0 & 6 & 48 & 0 & 7 & 5 & 3 & 7 & 32 & 8 & 12 & 0 & 7 \\
\hline $6 H-6,60-63$ & 47.5 & 2 & 19 & 0 & 94 & 120 & 0 & 16 & 1 & 2 & 31 & 0 & 6 & 7 & 5 & 2 & 24 & i & 16 & 2 & 13 \\
\hline $6 \mathrm{H}-\mathrm{CC}, 19-20$ & 48.2 & 1 & 19 & 2 & 79 & 126 & 0 & 21 & i & 3 & 18 & 0 & 2 & 4 & 4 & 6 & 27 & 3 & 20 & 3 & 9 \\
\hline \multicolumn{22}{|l|}{$141-860 \mathrm{~B}-$} \\
\hline $10 \mathrm{X}-\mathrm{CC}, 8-13$ & 69.5 & 1 & 19 & 4 & 82 & 77 & 0 & 13 & 0 & 1 & 84 & 0 & 8 & 20 & 2 & 2 & 31 & 2 & 16 & 1 & 1 \\
\hline $14 X-2,95-99$ & 101.3 & 1 & 19 & 0 & 32 & 69 & 0 & 16 & 0 & 0 & 104 & 0 & 16 & 9 & $i$ & 4 & 33 & 2 & 17 & 2 & 1 \\
\hline $17 \times-2,130-135$ & 129.3 & 1 & $18-16$ & 4 & 178 & 90 & 0 & 14 & 0 & 4 & 7 & 0 & 3 & 6 & i & 3 & 12 & 0 & 17 & 2 & 0 \\
\hline $19 X-1,31-33$ & 137.4 & 1 & $18-16$ & $i$ & 102 & 118 & 0 & 12 & 0 & 2 & 17 & 1 & 4 & 20 & 2 & 1 & 17 & 2 & 26 & $i$ & 5 \\
\hline $22 X-2,138-143$ & 167 & $i$ & $18-16$ & 2 & 97 & 136 & 0 & 18 & 0 & 4 & 16 & $i$ & 6 & 10 & 7 & 3 & 17 & 6 & 20 & 0 & 3 \\
\hline $22 X-3,22-27$ & 168.35 & $i$ & $18-16$ & $i$ & 97 & 130 & 0 & 20 & 0 & 3 & 13 & 2 & 9 & 12 & 9 & 6 & 19 & 5 & 13 & 1 & 2 \\
\hline $30 X-2,83-85$ & 243.9 & $i$ & $18-16$ & 2 & 71 & 122 & 0 & 16 & 0 & 1 & 30 & 2 & 9 & 29 & 2 & 3 & 17 & 2 & 23 & 2 & 3 \\
\hline $30 \times-3,13-18$ & 244.6 & 1 & $18-16$ & 0 & 81 & 140 & 0 & 17 & 0 & 0 & 37 & 0 & 23 & 15 & 5 & 2 & 21 & 5 & 9 & 0 & 2 \\
\hline $32 X-2,57-62$ & 262.97 & 2 & $18-16$ & 0 & 105 & 122 & 0 & 13 & 0 & 0 & 19 & 0 & 3 & 24 & $i$ & 3 & 27 & 3 & 14 & 1 & 1 \\
\hline $37 \mathrm{X}-1,132-134$ & 311.1 & 2 & $18-16$ & 0 & 8 & 22 & 0 & 2 & 0 & 0 & 3 & 0 & 2 & 5 & i & 2 & 4 & 4 & 0 & 0 & 0 \\
\hline $48 X-1,76-77$ & 406.7 & $i$ & $18-16$ & 5 & 37 & 15 & 0 & 8 & 0 & 0 & 0 & 0 & 2 & 0 & 2 & 2 & 0 & 0 & 3 & 2 & 0 \\
\hline $49 \mathrm{X}-1,28-32$ & 416 & $i$ & $18-16$ & 3 & 63 & 53 & 0 & 7 & 0 & 0 & 14 & 0 & 5 & 5 & $i$ & 1 & 4 & 0 & 8 & 0 & 0 \\
\hline $53 \mathrm{X}-2,26-31$ & 450.8 & 1 & $18-16$ & 0 & 13 & 28 & 0 & 3 & 0 & 0 & 3 & 0 & 2 & 0 & 2 & 2 & 1 & 2 & 8 & 2 & 0 \\
\hline $58 X-1,85-87$ & 493.6 & $1-2$ & $18-16$ & 2 & 43 & 52 & 0 & 2 & 0 & 1 & 10 & 1 & 6 & 6 & $i$ & $i$ & 3 & 1 & 10 & $i$ & 0 \\
\hline $58 \mathrm{X}-3,10-12$ & 495.9 & 1 & $18-16$ & 3 & 36 & 55 & 0 & 7 & 0 & $i$ & 8 & 4 & 1 & 3 & 0 & 2 & 8 & i & 28 & 0 & 0 \\
\hline \multicolumn{22}{|l|}{$141-861 \mathrm{IC}$} \\
\hline $3 \mathrm{H}-\mathrm{CC}, 27-30$ & 22 & 1 & 21 & 4 & 142 & 61 & 0 & 11 & 0 & 0 & 16 & 0 & 2 & 3 & 0 & 1 & 35 & 3 & 11 & 1 & 1 \\
\hline $6 \mathrm{H}-2,132-137$ & 43.8 & 1 & 20 & 3 & 110 & 94 & 0 & 19 & 0 & 3 & 59 & 0 & 4 & 3 & 2 & 2 & 22 & 1 & 16 & i & 1 \\
\hline $6 \mathrm{H}-3,15-17$ & 44.1 & i & 20 & 1 & 99 & 121 & 0 & 23 & 0 & 1 & 42 & 0 & 5 & 14 & 2 & 3 & 19 & 6 & 15 & 0 & i \\
\hline $6 \mathrm{H}-5,120-124$ & 48.2 & $i$ & 20 & 3 & 114 & 91 & 0 & 18 & 2 & $i$ & 69 & 0 & 4 & 9 & 3 & 3 & 23 & 1 & 12 & 0 & 0 \\
\hline $7 \mathrm{H}-5,129-134$ & 57.8 & 1 & 20 & 4 & 84 & 137 & 0 & 27 & 0 & 0 & 40 & 7 & 3 & 6 & 2 & 4 & 10 & 1 & 4 & 0 & 7 \\
\hline $10 \mathrm{H}-5,42-47$ & 77.4 & 1 & 20 & 1 & 47 & 57 & 0 & 7 & 0 & 0 & 19 & 0 & 8 & 3 & 0 & 4 & 4 & 3 & 11 & 0 & 0 \\
\hline $10 \mathrm{H}-2,66-68$ & 73.15 & i & 20 & 6 & 100 & 117 & 0 & 17 & 2 & 0 & 49 & 0 & 10 & 9 & 1 & 3 & 15 & 3 & 13 & 0 & 1 \\
\hline $14 X-2,146-148$ & 112.3 & 2 & 20 & 2 & 140 & 116 & 0 & 19 & 3 & 2 & 12 & 0 & 5 & 3 & 4 & 5 & 13 & 3 & 12 & 0 & i \\
\hline $32 X-2,32-34$ & 258.8 & 1 & $18-16$ & 1 & 73 & 49 & 0 & 4 & 0 & 0 & 5 & 0 & 5 & 0 & 0 & 0 & 2 & 4 & 14 & 0 & 2 \\
\hline \multicolumn{22}{|l|}{$141-862 \mathrm{~A}-$} \\
\hline 1H-2, 28-29 & 1.8 & I & $18-16$ & 3 & 96 & 116 & 0 & 17 & 0 & 0 & 29 & 0 & 7 & 7 & 1 & 1 & 10 & 4 & 12 & 0 & 4 \\
\hline $2 \mathrm{H}-1,134-136$ & 6.75 & $\mathrm{i}$ & $18-16$ & 10 & 105 & 104 & 0 & 12 & 0 & 1 & 8 & 0 & 12 & 6 & 5 & 2 & 10 & 6 & 12 & 2 & 1 \\
\hline $2 \mathrm{H}-2,23-24$ & 7.15 & 1 & $18-16$ & 4 & 102 & 100 & 0 & 18 & 1 & 1 & 9 & 0 & 17 & 10 & 2 & 4 & 12 & 11 & 20 & 2 & 1 \\
\hline $2 \mathrm{H}-5,7-9$ & 11.47 & $i$ & $18-16$ & 2 & 102 & 117 & 0 & 20 & 3 & 3 & 10 & 3 & 20 & 9 & 2 & 0 & 12 & 5 & 14 & 5 & 0 \\
\hline $3 \mathrm{H}-2,100-102$ & 17.4 & $i$ & $18-16$ & 4 & 110 & 98 & 0 & 14 & 0 & 1 & 8 & 0 & 8 & 5 & 2 & 2 & 13 & 4 & 13 & 0 & 1 \\
\hline
\end{tabular}




\begin{tabular}{|c|c|c|c|c|c|c|c|c|c|c|c|c|c|c|c|c|c|c|c|c|c|c|c|}
\hline $\begin{array}{l}\mathrm{Lvl} \\
\mathrm{Clgl}\end{array}$ & $\begin{array}{l}\text { Lvl } \\
\text { Blgl }\end{array}$ & $\begin{array}{l}\text { LvI } \\
\text { A/D }\end{array}$ & $\mathrm{Lmv}$ & $\mathrm{Lmm}$ & $\mathrm{Lmt}$ & Lma & Lmp & Lsi & Lsa & Lsc & Lsch & Glau & Org & $\begin{array}{c}\text { Bio } \\
\text { Sil }\end{array}$ & $\begin{array}{l}\text { Bio } \\
\text { Car }\end{array}$ & Carb & Mus & Biot & Chl & OpD & $\begin{array}{l}\text { Non } \\
\text { OpD }\end{array}$ & $\begin{array}{l}\text { Oth/ } \\
\text { Unk }\end{array}$ & Total \\
\hline 0 & 1 & 0 & 0 & 0 & 1 & 2 & 0 & 0 & 0 & 0 & 0 & 0 & 0 & 0 & 0 & 0 & 1 & 8 & 0 & 6 & 26 & 1 & 400 \\
\hline 0 & 6 & 0 & 0 & 0 & 3 & 0 & 1 & 0 & 0 & 0 & 0 & 0 & 0 & 0 & 1 & 0 & 0 & 0 & 0 & 4 & 13 & 0 & 400 \\
\hline 0 & 3 & 0 & 0 & 0 & 5 & 0 & 3 & 0 & 0 & 0 & 0 & 0 & 0 & i & 0 & 0 & 0 & 2 & 0 & 4 & 16 & 0 & 400 \\
\hline 0 & 2 & 0 & 0 & 3 & 1 & 3 & 0 & 0 & 6 & 0 & 0 & 0 & 0 & 1 & 0 & 0 & 4 & 18 & 1 & 7 & 18 & 0 & 400 \\
\hline 0 & 8 & 0 & 2 & 1 & 2 & 1 & 0 & 0 & 0 & 0 & 0 & 0 & 0 & 0 & 0 & 0 & 1 & 4 & 0 & 14 & 24 & 10 & 400 \\
\hline 0 & 2 & 0 & 0 & 1 & 3 & 0 & 1 & 0 & 1 & 0 & 0 & 0 & 0 & 0 & 0 & 0 & 1 & 7 & 1 & 5 & 32 & 0 & 400 \\
\hline 0 & 2 & 0 & 0 & 3 & 5 & 3 & 0 & 0 & 2 & 0 & 0 & 0 & 0 & 0 & 0 & 0 & 0 & 5 & $i$ & 3 & 23 & 13 & 400 \\
\hline 0 & 0 & 0 & 0 & 4 & 1 & 0 & 0 & 0 & 0 & 0 & 0 & 0 & 0 & 0 & 0 & 0 & 1 & 37 & 1 & 3 & 36 & 10 & 400 \\
\hline 0 & 0 & 0 & 0 & 5 & 11 & 2 & 0 & 0 & 3 & 0 & 0 & 1 & 0 & 0 & 1 & 0 & 0 & 4 & 0 & 1 & 2 & 1 & 400 \\
\hline 0 & 0 & 1 & 0 & 4 & 15 & 5 & 0 & 0 & 0 & 0 & 0 & 0 & I & 0 & 0 & 4 & 3 & 4 & 1 & 6 & 10 & 0 & 200 \\
\hline 0 & 1 & 0 & 0 & 11 & 14 & 4 & 0 & 0 & 0 & 1 & 0 & 0 & 0 & 0 & 2 & 0 & 3 & 5 & 1 & 6 & 3 & 4 & 400 \\
\hline 0 & 1 & 0 & 0 & 4 & 5 & 2 & 0 & 0 & 2 & 0 & 0 & 0 & 0 & 0 & 0 & 0 & 2 & 10 & 0 & 4 & 21 & 5 & 400 \\
\hline 0 & 2 & 0 & 0 & 3 & 7 & 8 & 1 & 0 & 0 & 0 & 0 & 0 & 1 & 0 & 0 & 0 & 0 & 3 & 0 & 4 & 13 & 7 & 400 \\
\hline 1 & 1 & 0 & 1 & 7 & 12 & 3 & 0 & 0 & 0 & 0 & 0 & 0 & 0 & 0 & 29 & 0 & 1 & 5 & 0 & 7 & 9 & 1 & 400 \\
\hline 0 & 2 & 0 & 0 & 5 & 10 & 11 & 2 & 0 & 0 & 0 & 0 & 0 & 0 & 1 & 21 & 0 & 2 & 1 & 0 & 1 & 20 & 0 & 400 \\
\hline 0 & 3 & 0 & 0 & 2 & 3 & 8 & 0 & 0 & 2 & 0 & 0 & 0 & I & 0 & 27 & 1 & 4 & 15 & 0 & 2 & 26 & 0 & 400 \\
\hline 1 & 1 & 0 & 0 & 7 & 11 & 5 & 1 & 0 & 1 & 0 & 0 & 0 & 0 & 0 & 4 & 1 & 0 & 7 & 0 & 1 & 11 & 0 & 400 \\
\hline 0 & 0 & 0 & 0 & 7 & 7 & 6 & 0 & 1 & 1 & 0 & 1 & 0 & 0 & 0 & 3 & 0 & 0 & 5 & 0 & 1 & 7 & 10 & 400 \\
\hline 0 & 4 & 0 & 0 & 10 & 12 & 3 & 0 & 0 & 3 & 0 & $\mathrm{i}$ & 0 & 0 & 0 & 2 & 0 & 4 & 3 & 0 & i & 9 & 0 & 400 \\
\hline 3 & 1 & 0 & 1 & 4 & 3 & 4 & 0 & 0 & 7 & 0 & 0 & 0 & 0 & 0 & I & 3 & 1 & 9 & 2 & 1 & 21 & 0 & 400 \\
\hline 0 & 6 & 1 & 1 & 5 & 6 & 4 & 0 & 0 & 3 & 0 & 2 & 0 & 0 & 0 & 0 & 0 & 0 & 3 & 2 & 0 & 17 & 10 & 400 \\
\hline 1 & 4 & 1 & 2 & 7 & 7 & 3 & 0 & 0 & 0 & 0 & 0 & 0 & 0 & 0 & 0 & 0 & 1 & 4 & 0 & 5 & 13 & 24 & 400 \\
\hline 0 & 0 & 0 & 0 & 3 & 1 & 1 & 0 & 0 & 1 & 0 & 0 & 0 & 2 & 4 & 0 & 0 & 3 & 21 & 2 & 5 & 13 & 0 & 400 \\
\hline 0 & 1 & 1 & 0 & 3 & 0 & 3 & 0 & 0 & 0 & 0 & 0 & 0 & 45 & 1 & 0 & 0 & 1 & 15 & 2 & 3 & 19 & 0 & 400 \\
\hline 0 & 2 & 1 & 0 & 6 & 11 & 2 & 0 & 0 & 1 & 0 & 0 & 0 & 2 & 1 & 9 & 1 & 1 & 3 & 0 & 4 & 15 & 0 & 400 \\
\hline 0 & 4 & 1 & 0 & 3 & 6 & 2 & 0 & 0 & 0 & 0 & 0 & 0 & 0 & 0 & 25 & 0 & 2 & 3 & 1 & 5 & 17 & 0 & 400 \\
\hline 1 & 4 & 0 & 0 & 5 & 5 & 0 & 2 & I & 1 & 0 & 0 & 0 & 0 & 0 & 2 & 0 & I & 6 & 0 & 2 & 24 & 0 & 400 \\
\hline 0 & 1 & 0 & 1 & 11 & 7 & 4 & 0 & 0 & 6 & 0 & 1 & 0 & 0 & 0 & 3 & 0 & 0 & 3 & 0 & 0 & 21 & 0 & 400 \\
\hline 1 & 2 & 0 & 0 & 1 & 2 & 1 & 0 & 0 & 1 & 0 & 0 & 0 & 0 & 0 & 3 & 0 & 0 & 4 & 0 & 9 & 42 & 0 & 400 \\
\hline 0 & 0 & 0 & 0 & 2 & 3 & 3 & 0 & 0 & 1 & 0 & 0 & 0 & 1 & 0 & 1 & 0 & 0 & 8 & 0 & 2 & 22 & 0 & 400 \\
\hline 1 & 6 & 1 & 0 & 6 & 6 & 0 & 0 & 0 & 0 & 0 & 0 & 0 & 0 & 1 & 9 & 0 & 1 & 9 & 4 & 2 & 18 & 0 & 400 \\
\hline 0 & 0 & 0 & 0 & 1 & 0 & 0 & 0 & 0 & 338 & 0 & 0 & 0 & 1 & 0 & 1 & 1 & 0 & 0 & 0 & 0 & 5 & 0 & 400 \\
\hline 0 & 0 & 0 & 0 & 3 & 5 & 1 & 0 & 0 & 1 & 0 & 0 & 0 & 0 & 2 & 0 & 0 & 3 & 1 & 0 & 3 & 5 & 0 & 100 \\
\hline 0 & 0 & 0 & 0 & 3 & 2 & 1 & 0 & 0 & $i$ & 0 & 1 & 0 & 1 & 0 & 0 & 0 & 0 & 2 & 1 & 8 & 15 & 1 & 200 \\
\hline 0 & 3 & 0 & 0 & 0 & 4 & 2 & 0 & 0 & 2 & 0 & 0 & 0 & 0 & 0 & 3 & 0 & I & 0 & 0 & 5 & 14 & 0 & 100 \\
\hline 0 & 1 & 0 & 0 & 2 & 9 & 1 & 1 & 1 & 2 & 0 & 0 & 0 & 1 & 1 & 7 & 0 & 0 & 0 & 0 & 6 & 21 & 7 & 200 \\
\hline 1 & 3 & 0 & 0 & 1 & 1 & 4 & 0 & 0 & 0 & 0 & 0 & 0 & 0 & 0 & 5 & 0 & 1 & 0 & 0 & 8 & 19 & 0 & 200 \\
\hline I & 1 & 0 & 0 & 7 & 17 & 2 & 0 & 0 & 0 & 0 & 0 & 0 & 0 & 1 & 43 & 4 & 2 & 6 & I & 7 & 17 & 0 & 400 \\
\hline 0 & 3 & 1 & 0 & 4 & 8 & 0 & 0 & 0 & 0 & 0 & 0 & 0 & 0 & 0 & 9 & 0 & 5 & 7 & 3 & 1 & 19 & 0 & 400 \\
\hline 0 & 0 & 0 & 1 & I & 12 & 0 & 2 & 0 & 1 & 0 & 0 & 0 & 0 & 1 & 2 & 0 & 0 & 4 & 1 & 3 & 20 & 0 & 400 \\
\hline 0 & 2 & 0 & 0 & 5 & 2 & 2 & 0 & 0 & 4 & 0 & 0 & 0 & 0 & 0 & 1 & 0 & 2 & 7 & 1 & 6 & 15 & 0 & 400 \\
\hline 1 & 4 & 1 & 0 & 2 & 7 & 10 & 0 & 0 & 0 & 0 & 3 & 0 & 0 & 0 & 0 & I & 0 & 4 & 0 & 0 & 31 & 0 & 400 \\
\hline 1 & 3 & 0 & 0 & 1 & 3 & 0 & 0 & 0 & 0 & 0 & 0 & 0 & 0 & 0 & 3 & 3 & 0 & 4 & 1 & 3 & 14 & 0 & 200 \\
\hline 0 & 1 & 0 & 0 & 6 & 4 & 2 & 0 & 0 & 3 & 0 & 0 & 0 & 0 & 0 & 0 & 0 & 1 & 11 & 0 & 4 & 22 & 0 & 400 \\
\hline 1 & 5 & 0 & 0 & 2 & 4 & 4 & 0 & 0 & 0 & 0 & 0 & 0 & 1 & 0 & 12 & 0 & 0 & 2 & 0 & 2 & 26 & 1 & 400 \\
\hline 0 & 0 & 0 & 0 & 4 & 9 & 2 & 0 & 0 & 0 & 0 & 0 & 0 & 0 & 0 & 5 & 0 & 0 & 2 & 1 & 3 & 15 & 0 & 200 \\
\hline 0 & 8 & 0 & 0 & 8 & 14 & 3 & 0 & 0 & 4 & 0 & 1 & 0 & 0 & 0 & 0 & 0 & 2 & 6 & 0 & 11 & 36 & 0 & 400 \\
\hline 0 & 1 & 1 & 0 & 13 & 40 & 9 & 2 & 0 & 0 & 0 & 0 & 0 & 1 & 0 & 4 & 1 & 2 & 11 & 1 & 2 & 16 & 0 & 400 \\
\hline 5 & 6 & 3 & 0 & 18 & 22 & 2 & 0 & 0 & 0 & 0 & 1 & 0 & 1 & 2 & 2 & 0 & 0 & 9 & 0 & 3 & 9 & 3 & 400 \\
\hline 1 & 1 & 1 & 0 & 13 & 10 & 5 & 0 & 0 & 0 & 0 & 0 & 0 & 0 & 0 & 0 & 0 & 0 & 10 & 0 & 3 & 27 & 2 & 400 \\
\hline 1 & 4 & 0 & 0 & 16 & 32 & 5 & 4 & 0 & 14 & 0 & 0 & 1 & 0 & 0 & 5 & 0 & 1 & 10 & 0 & 4 & 20 & 0 & 400 \\
\hline
\end{tabular}


APPENDIX 1 (continued).

\begin{tabular}{|c|c|c|c|c|c|c|c|c|c|c|c|c|c|c|c|c|c|c|c|c|c|}
\hline $\begin{array}{l}\text { Core, section, } \\
\text { interval }(\mathrm{cm})\end{array}$ & $\begin{array}{l}\text { Depth } \\
\text { (mbsf) }\end{array}$ & $\begin{array}{l}\text { Grain } \\
\text { size }\end{array}$ & $\begin{array}{c}\text { Age } \\
\text { (nannofossil } \\
\text { zone) }\end{array}$ & Qp & Qm & $\mathrm{P}$ & $\begin{array}{c}P \\
A / D\end{array}$ & K & $\begin{array}{l}\text { Unst } \\
\text { Feld }\end{array}$ & Lvo & $\begin{array}{l}\text { Lvv } \\
\text { Brgl }\end{array}$ & $\begin{array}{l}\text { Lvv } \\
\text { Orgl }\end{array}$ & $\begin{array}{l}\text { Lvv } \\
\mathrm{Clgl}\end{array}$ & $\begin{array}{l}\text { Lvv } \\
\text { Blgl }\end{array}$ & $\begin{array}{l}\text { Lvv } \\
\text { A/D }\end{array}$ & Lvf & $\begin{array}{c}\text { Lvml } \\
\mathrm{Brgl}\end{array}$ & $\begin{array}{c}\text { Lvml } \\
\mathrm{Clgl}\end{array}$ & $\begin{array}{c}\text { Lvml } \\
\text { Blgl }\end{array}$ & $\begin{array}{l}\text { Lvml } \\
\text { A/D }\end{array}$ & $\begin{array}{c}\text { Lvml } \\
\text { Brgl }\end{array}$ \\
\hline \multicolumn{22}{|l|}{$141-862 \mathrm{~B}-$} \\
\hline $2 X-1.44-46$ & 17.9 & 2 & $18-16$ & 4 & 124 & 119 & 0 & 21 & 1 & 7 & 9 & 0 & 5 & 10 & 1 & 0 & 12 & 7 & 10 & 0 & 4 \\
\hline $2 X-2.127-128$ & 20.3 & 1 & $18-16$ & 1 & 13 & 21 & 0 & 1 & 0 & 0 & 37 & 0 & 2 & 0 & 0 & 0 & 7 & 1 & 7 & 0 & 0 \\
\hline $2 X-C C .24-26$ & 21.4 & 1 & $18-16$ & 4 & 134 & 111 & 0 & 12 & 0 & 0 & 6 & 0 & 3 & 4 & 1 & 8 & 4 & 3 & 11 & 1 & 4 \\
\hline \multicolumn{22}{|l|}{$141-863 \mathrm{~A}$ - } \\
\hline IH-2. $124-126$ & 2.75 & 2 & $?$ & 2 & 157 & 104 & 0 & 15 & 0 & 2 & 14 & 0 & 3 & 3 & 0 & 2 & 6 & 0 & 12 & 1 & 1 \\
\hline IH-5. 15-17 & 6.15 & 2 & $?$ & 7 & 1.36 & 106 & 0 & 25 & 0 & 1 & 2 & 3 & 3 & 6 & 4 & 12 & 7 & 2 & 7 & 0 & 0 \\
\hline IH-CC. $27-29$ & 8.55 & 1 & $?$ & $i$ & 110 & 70 & 0 & 11 & 1 & i & 7 & 0 & 3 & 5 & 2 & 2 & 10 & 2 & 10 & 0 & 0 \\
\hline $2 \mathrm{H}-6.9-1 \mathrm{I}$ & 16.15 & 2 & ? & 3 & 99 & 140 & 0 & 14 & 0 & 0 & 26 & 0 & 18 & 4 & 0 & 8 & 8 & I & 6 & 0 & 2 \\
\hline $3 \mathrm{H}-2.57-6 \mathrm{I}$ & 20.2 & $i$ & ? & 6 & 70 & 81 & 0 & 13 & 2 & 2 & 18 & 0 & 10 & 2 & 0 & 5 & 11 & i & 7 & 0 & 1 \\
\hline $3 \mathrm{H}-2,128-133$ & 23.8 & i & $?$ & 7 & 165 & 100 & 0 & 21 & 2 & 3 & 9 & 0 & 7 & 3 & 1 & 4 & 7 & 3 & 14 & 1 & 0 \\
\hline $7 X-4.56-59$ & 61.15 & i & 20 & 5 & 103 & 134 & 0 & 14 & $\overline{1}$ & 0 & 11 & 0 & 2 & 5 & 4 & 2 & 12 & 1 & 34 & 8 & 0 \\
\hline $8 X-3.91-95$ & 69.4 & 2 & 20 & 2 & 150 & 104 & 0 & 12 & 0 & 3 & 20 & 0 & 4 & 9 & 2 & 0 & 10 & 0 & 9 & 0 & 0 \\
\hline $9 X-C C .13-15$ & 76.25 & $i$ & ? & 5 & 127 & 118 & 0 & 13 & 0 & 0 & 23 & i & 6 & 9 & 0 & 4 & 9 & 3 & 25 & 0 & 1 \\
\hline $10 X-C C .25-27$ & 85.35 & 2 & $?$ & 0 & 146 & 132 & 0 & 17 & 0 & i & 16 & 0 & 1 & 7 & 2 & 2 & 5 & 0 & 9 & 0 & 3 \\
\hline $11 \mathrm{X}-\mathrm{CC} .6-7$ & 94.76 & 2 & $?$ & 3 & 77 & 100 & 0 & 22 & 2 & 2 & 13 & 0 & 3 & 1 & 3 & 7 & 4 & 1 & 10 & 0 & 1 \\
\hline $14 X-2,31-36$ & 125 & 2 & $?$ & 3 & 106 & 116 & 0 & 23 & $\overline{1}$ & 2 & 16 & 1 & 6 & 18 & 5 & 1 & 18 & 2 & 21 & 0 & 2 \\
\hline $17 \mathrm{X}-\mathrm{CC} \cdot 17-20$ & 153.2 & 2 & $?$ & 2 & 99 & 147 & 0 & 22 & 0 & 2 & 17 & 0 & 3 & 6 & 3 & 4 & 14 & 0 & 18 & 1 & 0 \\
\hline $19 \mathrm{X}-1.48-51$ & 172.5 & 2 & $?$ & 6 & 123 & 88 & 0 & 26 & 0 & 0 & 12 & 0 & i & 1 & 5 & 10 & 9 & 3 & 8 & 5 & 0 \\
\hline $24 X-1,10-12$ & 220.4 & 2 & ? & 1 & 126 & 111 & 0 & 21 & 1 & 4 & 11 & 0 & i & 3 & 4 & 7 & 8 & 10 & 20 & 2 & 0 \\
\hline $26 \mathrm{X}-\mathrm{CC}, 14-16$ & 240.7 & 2 & 19 & 2 & 106 & 122 & 0 & II & i & 0 & 30 & 2 & 4 & 11 & 3 & 3 & 12 & 4 & 14 & 0 & 1 \\
\hline $28 X-1,69-71$ & 259.4 & 2 & 19 & 4 & 91 & 73 & 0 & 21 & 0 & 0 & 23 & 0 & 3 & 3 & 4 & 3 & 15 & 9 & 11 & 7 & 0 \\
\hline $28 \mathrm{X}-1,105-108$ & 259.85 & 1 & 19 & 2 & 96 & 131 & 0 & 18 & 1 & 2 & 15 & 0 & 4 & 13 & 0 & 2 & 15 & 6 & 19 & 0 & 1 \\
\hline $28 \mathrm{X}-\mathrm{CC}, 19-22$ & 260.25 & 1 & 19 & 1 & 98 & 115 & 0 & 10 & 0 & 6 & 22 & 0 & 6 & 3 & 6 & 4 & 18 & 9 & 16 & 5 & 2 \\
\hline $29 X-2,25-28$ & 269.45 & i & 19 & 4 & 89 & 134 & 0 & 16 & 1 & 3 & 17 & 0 & 2 & 0 & 1 & 4 & 9 & 2 & 24 & 8 & I \\
\hline $30 \times-1.3-7$ & 278.13 & 1 & 19 & 3 & 88 & 119 & 0 & 21 & 0 & I & 20 & 0 & 12 & 2 & 6 & 2 & 10 & 11 & 18 & 10 & I \\
\hline $30 X-C C .20-22$ & 280.7 & 1 & 19 & 2 & 102 & 144 & 0 & 13 & 0 & i & 13 & 0 & 10 & 2 & 2 & 7 & 13 & 18 & 9 & 2 & 2 \\
\hline $31 X-1,3-4$ & 287.63 & 2 & 19 & 4 & 107 & 109 & 0 & 16 & 2 & 0 & 13 & 0 & 3 & 1 & 5 & 2 & 15 & 12 & 10 & 7 & 4 \\
\hline $31 X-1,41-43$ & 288.05 & 1 & 19 & 7 & 80 & 131 & 0 & 21 & 0 & 3 & 22 & 0 & 7 & 6 & 5 & 1 & 14 & 2 & 19 & 10 & 2 \\
\hline \multicolumn{22}{|l|}{$141-863 \mathrm{~B}-$} \\
\hline $4 X-1,23-26$ & 326.13 & 2 & 20 & 3 & 123 & 113 & 0 & 19 & 1 & 1 & 8 & 0 & 3 & 10 & 2 & 4 & 4 & 2 & 9 & 2 & 2 \\
\hline $4 X-2,1-3$ & 327.4 & $1-2$ & 20 & 3 & 145 & 83 & 0 & 19 & 2 & 0 & 4 & 0 & 1 & I & 3 & 6 & 3 & 0 & 4 & 3 & 0 \\
\hline $4 \times-4.129-134$ & 331.7 & 2 & 20 & 2 & 120 & 110 & 0 & 27 & $\overline{0}$ & 2 & 11 & 0 & 2 & 9 & 6 & 3 & 9 & 4 & 10 & 1 & 0 \\
\hline $4 X-5 \cdot 2-7$ & 331.92 & $\overline{2}$ & 20 & $\overline{0}$ & 124 & 98 & 0 & 27 & 2 & 4 & 10 & 0 & 3 & 10 & 5 & $i$ & 16 & 1 & 11 & 3 & 0 \\
\hline $7 \mathrm{~N}-\mathrm{CC}+6$ & 357.3 & $\overline{2}$ & 20 & 5 & 70 & 76 & 0 & 4 & $\overline{4}$ & 2 & 18 & 0 & 2 & 4 & 2 & 4 & 5 & 4 & 13 & 2 & 0 \\
\hline $8 \mathrm{~N}-1.5-7$ & 357.45 & 2 & 20 & 1 & 116 & 89 & 0 & 18 & i & 3 & 2 & 0 & 0 & 0 & 8 & 1 & 8 & 1 & 1 & 7 & 0 \\
\hline $10 \mathrm{R}-1.68-71$ & 371.68 & 2 & 20 & 4 & 91 & 85 & 0 & 13 & 0 & 2 & 23 & 1 & 2 & 1 & 7 & 6 & 5 & 0 & 7 & 13 & 1 \\
\hline $12 R-1.38-40$ & 386.68 & 2 & 20 & 2 & 84 & 63 & 0 & 9 & 0 & 2 & 4 & 0 & 0 & 2 & 4 & 4 & 4 & 0 & 9 & 13 & 0 \\
\hline $13 R-1.41-43$ & 396.2 & $1-2$ & 20 & $\overline{4}$ & 123 & 105 & 0 & 15 & 0 & 3 & 13 & 0 & 2 & 2 & 6 & 10 & 4 & 2 & 5 & 4 & 1 \\
\hline $15 \mathrm{R}-1.1-3$ & 415.21 & 3 & 20 & 2 & 58 & 36 & 0 & 12 & 1 & 0 & 1 & 0 & 0 & 0 & 3 & 1 & 3 & 2 & 1 & 5 & 0 \\
\hline $16 \mathrm{R}-4,130-133$ & 430.5 & 2 & 20 & $\overline{2}$ & 107 & 78 & 4 & 11 & 2 & 0 & 0 & 0 & 0 & 1 & 8 & 5 & 2 & 1 & 5 & 16 & 0 \\
\hline $17 R-7.20-25$ & 443.1 & 2 & 20 & $i$ & 45 & 35 & 1 & 11 & 1 & 0 & 0 & 0 & 1 & 0 & 10 & 5 & 0 & 1 & 0 & 18 & 0 \\
\hline $19 R-3,102-105$ & 457.75 & 2 & 20 & 3 & 108 & 77 & 0 & 18 & 5 & 5 & 3 & 0 & 2 & 0 & 6 & 1 & I & 0 & 1 & 9 & 1 \\
\hline $21 \mathrm{R}-1.72-75$ & 473.7 & i & 20 & 1 & 101 & 110 & 1 & 11 & 0 & 2 & $i$ & 0 & 0 & 1 & 13 & 4 & 3 & 0 & 4 & 31 & 0 \\
\hline $22 \mathrm{R}-1.81-83$ & 483.5 & i & 20 & 6 & 100 & 111 & 0 & 14 & 1 & 0 & $i$ & 0 & 0 & 4 & 25 & 6 & 7 & 1 & 16 & 20 & 0 \\
\hline $24 \mathrm{R}-3,1 \mathrm{I}-13$ & 505.1 & i & 20 & 2 & 97 & 131 & 0 & 17 & 0 & 0 & 6 & 0 & 1 & i & 12 & 6 & 13 & 0 & 8 & 14 & 0 \\
\hline $25 \mathrm{R}-2.111-114$ & 514.3 & 1 & 20 & i & 130 & 126 & 1 & 17 & 1 & 0 & 11 & 0 & 2 & 0 & 9 & 2 & 13 & 0 & 3 & 13 & 0 \\
\hline $32 R-5,38-40$ & 585.1 & 1 & 20 & 3 & 82 & 82 & 0 & 10 & 5 & 3 & 2 & 0 & 1 & 2 & 4 & 2 & 3 & 1 & 9 & 9 & 1 \\
\hline $34 R-5,70-73$ & 604.7 & I & 20 & 1 & 127 & 121 & 0 & 24 & 2 & 0 & 3 & 0 & 0 & 6 & 8 & 2 & 9 & 3 & 8 & 12 & 0 \\
\hline $35 \mathrm{R}-1.4-6$ & 608.1 & 1 & 20 & 2 & 131 & 134 & 0 & 24 & $\overline{1}$ & 1 & 5 & 0 & I & 1 & 8 & 6 & 5 & 3 & 5 & 8 & 0 \\
\hline $37 R-4.77-80$ & 632.2 & $1-2$ & 20 & i & 125 & 109 & 1 & 16 & 0 & 3 & 6 & 0 & $i$ & 0 & 11 & 5 & 5 & 3 & 11 & 9 & 0 \\
\hline $39 R-2.105-107$ & 648.7 & 1 & 20 & 0 & 62 & 101 & 0 & 16 & 0 & 1 & 9 & 0 & 0 & 1 & 16 & 5 & 5 & 0 & 3 & 11 & 2 \\
\hline $42 R-2,62-64$ & 677.3 & $i$ & 20 & 5 & 118 & 107 & 5 & 21 & 3 & 0 & 0 & 0 & 0 & 3 & 7 & 4 & 5 & 0 & 10 & 10 & 0 \\
\hline $43 R-2,73-75$ & 687 & $1-2$ & 20 & 3 & 119 & 89 & 1 & 26 & 1 & 0 & 2 & 0 & 2 & 1 & 7 & 3 & 5 & 2 & 13 & 11 & 0 \\
\hline $44 R-5,43-46$ & 700.7 & 1 & 20 & 4 & 117 & 134 & 0 & 17 & 5 & 0 & 7 & 0 & 0 & 4 & 4 & 4 & 13 & 2 & 16 & 2 & 1 \\
\hline $45 R-2,60-63$ & 705.8 & 2 & 20 & 2 & 127 & 126 & 0 & 32 & 1 & 0 & 5 & 0 & 3 & 0 & 5 & 7 & 12 & 2 & 0 & 4 & 0 \\
\hline $46 \mathrm{R}-2.62-66$ & 708.9 & 1 & 20 & 3 & 94 & 68 & 3 & 15 & 1 & 1 & 3 & 0 & 0 & 0 & 2 & 3 & 6 & 0 & 5 & 4 & 0 \\
\hline $47 \mathrm{R}-1,111-122$ & 714.9 & $1-2$ & 20 & 4 & 78 & 68 & 0 & 13 & 0 & i & 3 & 0 & 1 & 1 & 5 & 2 & 3 & 0 & 1 & 16 & 0 \\
\hline $49 \mathrm{R}-1,86-89$ & 734 & 1 & 20 & 3 & 117 & 135 & 3 & 17 & 0 & 0 & 2 & 0 & 0 & 1 & 7 & 1 & 3 & 0 & 10 & 15 & 0 \\
\hline
\end{tabular}

Notes: Grain size: 1 = very fine, 2 = fine, 3 = medium. See Table 1 for key to abbreviations and formulas. 


\begin{tabular}{|c|c|c|c|c|c|c|c|c|c|c|c|c|c|c|c|c|c|c|c|c|c|c|c|}
\hline $\begin{array}{l}\text { Lvl } \\
\text { Clgl }\end{array}$ & $\begin{array}{l}\text { Lvl } \\
\text { Blgl }\end{array}$ & $\begin{array}{l}\text { Lvl } \\
\text { A/D }\end{array}$ & Lmv & Lmm & Lmt & Lma & Lmp & Lsi & Lsa & Lsc & Lsch & Glau & Org & $\begin{array}{c}\text { Bio } \\
\text { Sil }\end{array}$ & $\begin{array}{l}\text { Bio } \\
\text { Car }\end{array}$ & Carb & Mus & Biot & $\mathrm{Chl}$ & OpD & $\begin{array}{l}\text { Non } \\
\text { OpD }\end{array}$ & $\begin{array}{l}\text { Oth/ } \\
\text { Unk }\end{array}$ & Total \\
\hline 0 & 1 & 0 & 0 & 3 & 15 & 4 & 0 & 0 & 2 & 2 & 3 & 0 & 0 & 0 & 0 & 3 & 0 & 5 & 0 & 4 & 22 & 2 & 400 \\
\hline 0 & 0 & 0 & 0 & 2 & 1 & i & 0 & 0 & $\overline{0}$ & 0 & 0 & 0 & 0 & 0 & 0 & 0 & 0 & 3 & 0 & i & 2 & 0 & 100 \\
\hline 0 & 3 & 0 & 0 & 9 & 28 & 8 & 1 & 0 & 0 & 0 & 0 & 0 & 0 & 0 & 4 & 0 & 2 & 8 & 0 & 14 & 17 & 0 & 400 \\
\hline 0 & 0 & 0 & 0 & 1 & 24 & 8 & 0 & 1 & 6 & 0 & 0 & 0 & 2 & 3 & 6 & 0 & 0 & 9 & 3 & 6 & 9 & 0 & 400 \\
\hline 0 & 3 & 0 & 0 & 6 & 22 & 7 & 0 & 0 & 0 & 0 & 0 & 0 & $i$ & 0 & 6 & 0 & 1 & 5 & 0 & 5 & 23 & 0 & 400 \\
\hline 0 & 2 & 0 & 0 & 7 & 11 & 4 & 0 & 0 & 0 & 0 & 0 & 0 & 0 & 2 & 3 & 0 & 2 & 2 & 1 & 6 & 25 & 0 & 300 \\
\hline 0 & 2 & 0 & 0 & 5 & 12 & 3 & 0 & 0 & 1 & 0 & 0 & 0 & 2 & 0 & 0 & 0 & 0 & 11 & i & 4 & 29 & 1 & 400 \\
\hline 0 & 2 & 1 & 0 & 5 & 6 & 2 & 0 & 1 & 6 & 0 & 0 & 0 & 1 & 1 & 6 & 1 & 0 & 8 & 0 & 11 & 20 & 0 & 300 \\
\hline 0 & 2 & 0 & 0 & 2 & 11 & 4 & 0 & 0 & 0 & 0 & 0 & 0 & 0 & 0 & 5 & 0 & 2 & 2 & 1 & 5 & 19 & 0 & 400 \\
\hline 0 & 6 & 3 & 0 & 3 & 5 & 3 & 0 & 0 & 3 & 1 & 0 & 0 & 0 & 0 & 0 & 0 & 0 & 9 & 0 & 2 & 29 & 0 & 400 \\
\hline 1 & 1 & 0 & 0 & 11 & 15 & 4 & 0 & 0 & 0 & 0 & 1 & 0 & 0 & 0 & 4 & 0 & 1 & 8 & 3 & 2 & 24 & 0 & 400 \\
\hline 0 & 1 & 0 & 0 & 6 & 11 & 2 & 0 & 0 & 3 & 0 & 0 & 0 & 0 & 0 & 7 & i & i & 5 & 0 & 1 & 17 & I & 400 \\
\hline 0 & 1 & 0 & 0 & 4 & 12 & 6 & 0 & 0 & 0 & 0 & 0 & 0 & 0 & 0 & 0 & 0 & 0 & 0 & 0 & 3 & 33 & 0 & 400 \\
\hline 0 & 3 & 1 & 0 & 4 & 4 & 2 & 0 & 0 & 0 & 0 & 0 & 0 & 0 & 0 & 0 & 2 & 0 & 0 & 3 & 4 & 28 & 0 & 300 \\
\hline 0 & 2 & 0 & 0 & 5 & 7 & 0 & 1 & 0 & 0 & 0 & 0 & 0 & I & 0 & 1 & 0 & 1 & 5 & 0 & 2 & 33 & 1 & 400 \\
\hline 0 & 3 & 0 & 0 & 3 & 13 & 2 & 3 & 0 & 0 & 0 & 0 & 0 & 0 & 0 & 0 & 0 & 2 & 6 & 1 & 1 & 28 & 0 & 400 \\
\hline 0 & 3 & 1 & 0 & 2 & 14 & 17 & 0 & 16 & 22 & 0 & 0 & 0 & 0 & 1 & 4 & 1 & 1 & 8 & 0 & 4 & 8 & 1 & 400 \\
\hline 1 & 0 & i & 0 & 5 & 12 & 8 & 0 & 0 & 1 & 0 & i & 0 & i & 0 & 11 & 3 & 0 & 4 & 0 & 2 & 20 & 0 & 400 \\
\hline 2 & 4 & 0 & 0 & 2 & 13 & 2 & 0 & 0 & 4 & 0 & i & 0 & 0 & 1 & 4 & 0 & 0 & 10 & 0 & 5 & 26 & 0 & 400 \\
\hline 5 & 1 & 0 & 0 & 8 & 19 & 17 & 4 & 12 & 37 & 0 & i & 0 & 0 & 0 & 5 & 0 & 0 & 2 & 0 & 4 & 13 & 5 & 400 \\
\hline 1 & 2 & 1 & 0 & 9 & 17 & 1 & 0 & 0 & 1 & 0 & 0 & 0 & 0 & 0 & I & 0 & 2 & 3 & 3 & 5 & 27 & 2 & 400 \\
\hline 0 & 1 & 0 & 0 & 3 & 13 & 6 & 0 & 0 & 5 & 0 & 0 & 0 & 0 & 0 & 5 & 0 & 0 & 14 & 0 & 5 & 22 & 5 & 400 \\
\hline 1 & 1 & 2 & 0 & 5 & 17 & 4 & 0 & 2 & 5 & 0 & 0 & 0 & 0 & 0 & 1 & 0 & 0 & 4 & 0 & 13 & 30 & 0 & 400 \\
\hline 4 & 1 & 2 & 0 & 4 & 7 & 5 & 0 & 0 & 5 & 0 & 0 & 0 & 0 & 0 & 6 & 0 & 0 & 6 & 0 & 10 & 26 & 0 & 400 \\
\hline 2 & 1 & 0 & 0 & 6 & 12 & 1 & 0 & 0 & 1 & 0 & 1 & 0 & 1 & 0 & 0 & 0 & 0 & 4 & 0 & 6 & 25 & 0 & 400 \\
\hline 7 & 1 & 5 & I & 2 & 19 & 14 & 2 & 3 & 3 & 0 & 0 & 0 & 0 & 0 & 2 & 0 & 0 & 4 & 0 & 2 & 17 & 8 & 400 \\
\hline 0 & 3 & 1 & 0 & 3 & 10 & 6 & 0 & 1 & 7 & 0 & 0 & 0 & 0 & 0 & 3 & 0 & 0 & 4 & 0 & 11 & 21 & 0 & 400 \\
\hline 2 & 3 & 1 & 0 & 4 & 12 & 10 & 0 & 2 & 3 & 0 & 0 & 0 & 0 & 0 & 3 & 0 & 0 & 1 & 0 & 5 & 48 & 0 & 400 \\
\hline 1 & 1 & 0 & 0 & $i$ & 8 & 2 & 0 & 0 & i & 0 & 0 & 0 & 0 & 0 & 0 & 0 & 0 & 0 & 0 & 0 & 9 & 0 & 300 \\
\hline 0 & 5 & 0 & 0 & 14 & 17 & 6 & 4 & 1 & 2 & 0 & 1 & 0 & 0 & 0 & 2 & 0 & 0 & 6 & 0 & 2 & 24 & 0 & 400 \\
\hline I & 2 & 0 & 0 & 6 & 16 & 9 & 0 & 14 & 12 & 0 & 0 & 0 & 0 & 0 & $\overline{0}$ & 0 & 3 & 2 & 0 & $i$ & 18 & $i$ & 400 \\
\hline 0 & 1 & 0 & 0 & 6 & 18 & 1 & 2 & 6 & 109 & 0 & 0 & 0 & 7 & 0 & 6 & 0 & 1 & 5 & 0 & 6 & 16 & 1 & 400 \\
\hline 1 & i & 2 & 0 & I & 32 & 10 & 6 & 13 & 43 & 0 & 0 & 0 & 0 & 0 & 2 & 0 & 0 & 1 & 0 & 3 & 29 & 0 & 400 \\
\hline 1 & 6 & 3 & 0 & 4 & 19 & 22 & 0 & 13 & 45 & 0 & 0 & 0 & 0 & 0 & 1 & 0 & I & i & 0 & 4 & 13 & 6 & 400 \\
\hline 0 & 2 & 1 & 0 & 3 & 21 & 9 & 2 & 21 & 113 & 2 & 0 & 0 & 0 & 0 & 0 & I & 0 & 0 & 0 & 2 & 19 & 4 & 400 \\
\hline 0 & 1 & 0 & 0 & 5 & 15 & 5 & 2 & 15 & 38 & 0 & I & 0 & 0 & 0 & 3 & 0 & 0 & 1 & 0 & 5 & 10 & 0 & 400 \\
\hline 1 & 0 & 4 & 0 & 2 & 15 & 22 & 8 & 153 & 59 & 0 & 0 & 0 & 0 & 0 & 0 & 0 & 0 & 3 & 0 & 0 & 2 & 6 & 400 \\
\hline 0 & 0 & 3 & 0 & 3 & 32 & 6 & 0 & 12 & 45 & 0 & 0 & 0 & 0 & 0 & 0 & 0 & 0 & 2 & 0 & 5 & 48 & 2 & 400 \\
\hline i & 0 & 4 & 0 & 0 & 14 & 14 & 8 & 48 & 67 & 2 & 0 & 0 & 0 & 0 & 3 & 0 & 0 & $i$ & 0 & $i$ & 3 & 5 & 300 \\
\hline 0 & $i$ & 3 & 4 & 6 & 47 & 12 & 3 & 5 & 40 & $i$ & 0 & 0 & 0 & 0 & 2 & 0 & i & 3 & 0 & 5 & 17 & 10 & 400 \\
\hline 0 & 0 & I & 0 & 6 & 18 & 9 & 0 & 6 & 45 & 0 & 1 & 0 & 0 & 0 & 6 & 0 & 0 & 1 & 0 & $i$ & 17 & 6 & 400 \\
\hline 0 & 1 & 0 & 0 & 8 & 17 & 7 & 2 & 5 & 21 & 0 & 0 & 0 & 0 & 0 & 0 & 0 & 0 & 3 & 0 & 2 & 22 & 0 & 400 \\
\hline 0 & 0 & 1 & 0 & 6 & 15 & 7 & $i$ & i & 15 & 0 & 0 & 0 & 0 & 0 & 4 & i & 0 & 2 & 0 & 5 & 33 & I & 400 \\
\hline 0 & 1 & i & 0 & 2 & 8 & 6 & 0 & i & 23 & 0 & 0 & 0 & 0 & 0 & 1 & 0 & 0 & 7 & 0 & 2 & 14 & 5 & 400 \\
\hline 0 & $i$ & i & 0 & 1 & 8 & 3 & 0 & 8 & 9 & 0 & 0 & 1 & 0 & 0 & 0 & 1 & 0 & $i$ & 0 & 2 & 10 & 2 & 267 \\
\hline 0 & 1 & 0 & 0 & 3 & 14 & 3 & 2 & 7 & 17 & 0 & 0 & 0 & 0 & 0 & 0 & 0 & I & 7 & 0 & 2 & 9 & 8 & 400 \\
\hline 0 & 0 & 2 & 0 & 10 & 9 & 5 & 0 & 0 & 4 & 0 & 0 & 0 & 0 & 0 & 2 & 0 & i & 2 & 0 & 4 & 25 & 1 & 400 \\
\hline 0 & 1 & 1 & 0 & 2 & 14 & 5 & 1 & 5 & 10 & 1 & 0 & 0 & 0 & 0 & $i$ & i & 0 & 5 & 0 & 8 & 38 & 4 & 400 \\
\hline 0 & i & 0 & 0 & 3 & 9 & 3 & 0 & 7 & 13 & 0 & 0 & 0 & 0 & 0 & 0 & 0 & 0 & $i$ & 0 & 4 & 12 & 0 & 285 \\
\hline 0 & 0 & 0 & 0 & 8 & 18 & 5 & I & 8 & 35 & 0 & 0 & 0 & 0 & 0 & 1 & 0 & 0 & 3 & 0 & 4 & 18 & 1 & 400 \\
\hline 0 & 3 & 4 & 0 & 8 & 16 & 6 & 0 & 7 & 39 & 0 & 0 & 0 & 0 & 0 & 3 & 0 & 0 & 10 & 1 & 5 & 12 & i & 400 \\
\hline 0 & 0 & 1 & 0 & 3 & 12 & 10 & 2 & 6 & 9 & 0 & 0 & 0 & 0 & 0 & 0 & 0 & 0 & 4 & 0 & 4 & 18 & i & 400 \\
\hline 0 & 0 & 0 & 0 & 2 & 23 & 3 & 0 & 0 & 8 & 0 & 1 & 0 & 0 & 0 & 3 & 0 & 0 & 9 & 0 & i & 24 & 0 & 400 \\
\hline 0 & 0 & 0 & 0 & 2 & 14 & 13 & 0 & 25 & 110 & 1 & 0 & 0 & 0 & 0 & 5 & 0 & 0 & 3 & 0 & 2 & 13 & 4 & 400 \\
\hline 1 & i & 2 & 4 & 4 & 12 & 12 & 0 & 8 & 38 & 0 & 0 & 0 & 0 & 0 & $i$ & 0 & 0 & 0 & 0 & $i$ & 7 & 3 & 290 \\
\hline 0 & 0 & 3 & 0 & 5 & 8 & 8 & I & 4 & 35 & 0 & 0 & 0 & 0 & 0 & 6 & 0 & 0 & 2 & 0 & 3 & 10 & 1 & 400 \\
\hline
\end{tabular}


APPENDIX 2

Recalculated Parameters

\begin{tabular}{|c|c|c|c|c|c|c|c|c|c|c|c|c|c|c|}
\hline \multirow{2}{*}{$\begin{array}{l}\text { Core, section, } \\
\text { interval }(\mathrm{cm})\end{array}$} & & QFL & & & QmKP & & & mLvLs & & & ILvbrLvi & & FR\% & $\mathrm{Fr} \%$ \\
\hline & $\% \mathrm{Q}$ & $\% \mathrm{~F}$ & $\% \mathrm{~L}$ & $\% \mathrm{Qm}$ & $\% \mathrm{~K}$ & $\% \mathrm{P}$ & $\% \mathrm{Lm}$ & $\% \mathrm{Lv}$ & $\%$ Ls & $\%$ Lvel & \%Lvbr & $\%$ Lvbl & Mica & D \\
\hline $141-859 \mathrm{~A}-$ & & & & & & & & & & & & & & \\
\hline $3 \mathrm{H}-2,24-25$ & 15.9 & 44.4 & 39.7 & 26.0 & 5.1 & 68.8 & 2.1 & 97.9 & 0.0 & 12.0 & 56.0 & 32.0 & 2.3 & 8.0 \\
\hline $3 \mathrm{H}-3,115-116$ & 13.1 & 39.3 & 47.6 & 24.6 & 6.0 & 69.3 & 2.2 & 97.8 & 0.0 & 2.3 & 30.2 & 67.4 & 0.0 & 4.3 \\
\hline $6 \mathrm{X}-1,96-98$ & 27.9 & 43.8 & 28.4 & 38.7 & 3.0 & 58.4 & 7.5 & 92.5 & 0.0 & 20.0 & 41.1 & 38.9 & 0.5 & 5.0 \\
\hline $2 R-4,1-5$ & 34.8 & 31.1 & 34.2 & 52.2 & 5.3 & 42.5 & 5.8 & 89.2 & 5.0 & 20.8 & 42.5 & 36.8 & 5.8 & 6.3 \\
\hline $16 \mathrm{R}-3,146-149$ & 23.9 & 47.3 & 28.8 & 32.2 & 5.4 & 62.4 & 6.0 & 94.0 & 0.0 & 10.0 & 58.8 & 31.3 & 1.3 & 9.5 \\
\hline $17 \mathrm{R}-1,32-34$ & 27.7 & 48.6 & 23.7 & 35.8 & 5.6 & 58.6 & 6.0 & 92.9 & 1.2 & 13.6 & 30.5 & 55.9 & 2.3 & 9.3 \\
\hline $17 R-4,74-76$ & 31.3 & 46.2 & 22.5 & 38.8 & 6.7 & 54.5 & 13.8 & 83.8 & 2.5 & 11.8 & 31.4 & 56.9 & 1.5 & 6.6 \\
\hline $19 \mathrm{R}-1,79-81$ & 23.7 & 58.0 & 18.3 & 29.0 & 5.1 & 65.9 & 8.8 & 91.2 & 0.0 & 16.1 & 38.7 & 45.2 & 9.8 & 9.8 \\
\hline $33 \mathrm{R}-2,61-63$ & 64.6 & 26.4 & 9.0 & 70.8 & 6.8 & 22,4 & 51.4 & 40.0 & 8.6 & 0.0 & 100.0 & 0.0 & 1.0 & 0.8 \\
\hline $37 \mathrm{R}-\mathrm{CC}, 5-9$ & 64.3 & 17.5 & 18.1 & 77.6 & 4.5 & 17.9 & 77.4 & 22.6 & 0.0 & 50.0 & 50.0 & 0.0 & 4.0 & 8.0 \\
\hline $38 \mathrm{R}-\mathrm{CC}, 8-10$ & 58.0 & 27.1 & 14.9 & 67.7 & 7.3 & 25.0 & 51.8 & 46.4 & 1.8 & 33.3 & 58.3 & 8.3 & 2.3 & 2.3 \\
\hline $\begin{array}{l}141-860 \mathrm{~A}- \\
1 \mathrm{H}-\mathrm{CC}, 2-3\end{array}$ & 28.2 & 38.5 & 33.2 & 413 & 6.4 & 52.3 & 9.2 & 891 & 17 & 8.7 & 511 & 40.2 & 30 & 63 \\
\hline 141-860B- & & & & & & & & & & & & & & \\
\hline $2 \mathrm{H}-6,110-112$ & 34.4 & 36.0 & 29.6 & 48.3 & 8.9 & 42.9 & 17.3 & 82.7 & 0.0 & 0.0 & 59.7 & 40.3 & 0.8 & 4.3 \\
\hline $3 \mathrm{H}-4,139-142$ & 37.9 & 34.5 & 27.6 & 51.8 & 8.4 & 39.8 & 24.0 & 76.0 & 0.0 & 7.5 & 53.7 & 38.8 & 1.5 & 4.1 \\
\hline $3 \mathrm{H}-7,30-35$ & 33.6 & 31.9 & 34.5 & 50.4 & 9.6 & 39.9 & 23.0 & 77.0 & 0.0 & 10.5 & 59.3 & 30.2 & 0.8 & 5.3 \\
\hline $4 \mathrm{H}-2,140-143$ & 34.9 & 31.8 & 33.3 & 50.2 & 6.3 & 43.5 & 12.0 & 86.1 & 1.9 & 5.7 & 46.6 & 47.7 & 4.8 & 7.0 \\
\hline $5 \mathrm{H}-5,113-116$ & 30.9 & 35.4 & 33.8 & 45.9 & 11.4 & 42.7 & 18.9 & 80.3 & 0.8 & 13.3 & 61.2 & 25.5 & 1.8 & 3.1 \\
\hline $5 \mathrm{H}-7,35-40$ & 32.6 & 31.8 & 35.6 & 49.8 & 6.3 & 43.9 & 15.0 & 82.7 & 2.3 & 13.1 & 69.7 & 17.2 & 1.3 & 2.1 \\
\hline $5 \mathrm{H}-\mathrm{CC}, 141-144$ & 33.1 & 31.0 & 36.0 & 50.2 & 6.8 & 43.0 & 18.2 & 78.8 & 2.9 & 6.1 & 62.2 & 31.6 & 1.8 & 2.6 \\
\hline $6 \mathrm{H}-3,76-79$ & 19.6 & 36.7 & 43.6 & 34.8 & 6.9 & 58.3 & 7.6 & 88.0 & 4.4 & 14.6 & 70.7 & 14.6 & 3.0 & 5.6 \\
\hline $6 \mathrm{H}-6,60-63$ & 25.5 & 37.2 & 37.2 & 40.7 & 6.9 & 52.4 & 11.7 & 84.7 & 3.6 & 6.7 & 65.4 & 27.9 & 1.3 & 4.3 \\
\hline $6 \mathrm{H}-\mathrm{CC}, 19-20$ & 22.9 & 41.9 & 35.1 & 34.8 & 9.3 & 55.9 & 15.3 & 84.7 & 0.0 & 6.8 & 61.4 & 31.8 & 1.3 & 4.6 \\
\hline $10 \mathrm{X}-\mathrm{CC}, 8-13$ & 24.6 & 25.7 & 49.7 & 47.7 & 7.6 & 44.8 & 2.9 & 96.6 & 0.6 & 6.2 & 71.6 & 22.2 & 6.5 & 4.6 \\
\hline $14 X-2,95-99$ & 10.2 & 27.1 & 62.7 & 27.4 & 13.7 & 59.0 & 3.0 & 97.0 & 0.0 & 9.8 & 75.4 & 14.8 & 4.5 & 5.6 \\
\hline $17 \mathrm{X}-2,130-135$ & 50.0 & 28.6 & 21.4 & 63.1 & 5.0 & 31.9 & 24.4 & 74.4 & 1.3 & 6.4 & 40.4 & 53.2 & 1.0 & 4.8 \\
\hline $19 X-1,31-33$ & 29.7 & 37.5 & 32.9 & 44.0 & 5.2 & 50.9 & 9.6 & 90.4 & 0.0 & 6.3 & 41.1 & 52.6 & 1.5 & 5.6 \\
\hline $22 X-2,138-143$ & 27.1 & 42.2 & 30.7 & 38.6 & 7.2 & 54.2 & 10.7 & 87.5 & 1.8 & 15.7 & 43.4 & 41.0 & 1.8 & 6.5 \\
\hline $22 X-3,22-27$ & 26.3 & 40.2 & 33.5 & 39.3 & 8.1 & 52.6 & 18.4 & 76.0 & 5.6 & 18.9 & 45.9 & 35.1 & 0.8 & 5.3 \\
\hline $30 X-2,83-85$ & 21.3 & 40.4 & 38.3 & 34.0 & 7.7 & 58.4 & 3.1 & 96.2 & 0.8 & 10.3 & 43.1 & 46.6 & 1.0 & 12.8 \\
\hline $30 X-3,13-18$ & 22.1 & 42.9 & 35.0 & 34.0 & 7.1 & 58.8 & 6.3 & 93.0 & 0.8 & 25.0 & 53.6 & 21.4 & 2.0 & 6.0 \\
\hline $32 X-2,57-62$ & 29.5 & 37.9 & 32.6 & 43.8 & 5.4 & 50.8 & 10.3 & 89.7 & 0.0 & 7.1 & 48.0 & 44.9 & 3.5 & 5.0 \\
\hline $37 X-1,132-134$ & 2.0 & 6.1 & 91.8 & 25.0 & 6.3 & 68.8 & 0.3 & 5.8 & 93.9 & 33.3 & 38.9 & 27.8 & 0.0 & 1.3 \\
\hline $48 X-1,76-77$ & 48.8 & 26.7 & 24.4 & 61.7 & 13.3 & 25.0 & 42.9 & 52.4 & 4.8 & 40.0 & 0.0 & 60.0 & 4.0 & 8.0 \\
\hline $49 X-1,28-32$ & 38.4 & 34.9 & 26.7 & 51.2 & 5.7 & 43.1 & 13.0 & 82.6 & 4.3 & 13.9 & 50.0 & 36.1 & 1.5 & 11.5 \\
\hline $53 X-2,26-31$ & 16.9 & 40.3 & 42.9 & 29.5 & 6.8 & 63.6 & 18.2 & 75.8 & 6.1 & 21.1 & 21.1 & 57.9 & 1.0 & 19.0 \\
\hline $58 X-1,85-87$ & 28.7 & 34.4 & 36.9 & 44.3 & 2.1 & 53.6 & 22.4 & 72.4 & 5.2 & 18.9 & 35.1 & 45.9 & 0.0 & 13.5 \\
\hline $58 X-3,10-12$ & 23.4 & 37.1 & 39.5 & 36.7 & 7.1 & 56.1 & 9.1 & 90.9 & 0.0 & 5.7 & 30.2 & 64.2 & 0.5 & 13.5 \\
\hline $141-861 \mathrm{C}$ & & & & & & & & & & & & & & \\
\hline $3 \mathrm{H}-\mathrm{CC}, 27-30$ & 45.8 & 22.6 & 31.7 & 66.4 & 5.1 & 28.5 & 25.7 & 74.3 & 0.0 & 8.2 & 71.2 & 20.5 & 2.3 & 6.1 \\
\hline $6 \mathrm{H}-2,132-137$ & 31.7 & 31.7 & 36.5 & 49.3 & 8.5 & 42.2 & 9.2 & 90.8 & 0.0 & 4.6 & 75.2 & 20.2 & 3.8 & 5.1 \\
\hline $6 \mathrm{H}-3,15-17$ & 27.1 & 39.0 & 33.9 & 40.7 & 9.5 & 49.8 & 12.8 & 86.4 & 0.8 & 10.8 & 60.8 & 28.4 & 1.3 & 5.8 \\
\hline $6 \mathrm{H}-5,120-124$ & 31.8 & 30.2 & 38.0 & 50.7 & 8.0 & 41.3 & 6.4 & 90.7 & 2.9 & 4.2 & 76.7 & 19.2 & 2.5 & 5.3 \\
\hline $7 \mathrm{H}-5,129-134$ & 24.2 & 45.1 & 30.8 & 33.9 & 10.9 & 55.2 & 17.0 & 80.4 & 2.7 & 6.6 & 75.0 & 18.4 & 1.0 & 7.8 \\
\hline $10 \mathrm{H}-5,42-47$ & 27.9 & 37.2 & 34.9 & 42.3 & 6.3 & 51.4 & 6.7 & 93.3 & 0.0 & 23.1 & 44.2 & 32.7 & 2.5 & 8.5 \\
\hline $10 \mathrm{H}-2,66-68$ & 29.3 & 37.6 & 33.1 & 42.4 & 7.2 & 50.4 & 10.0 & 87.5 & 2.5 & 12.9 & 64.4 & 22.8 & 3.0 & 6.5 \\
\hline $14 X-2,146-148$ & 39.9 & 38.8 & 21.3 & 50.4 & 6.8 & 42.8 & 13.2 & 86.8 & 0.0 & 16.4 & 47.3 & 36.4 & 0.5 & 7.0 \\
\hline $32 X-2,32-34$ & 42.5 & 30.5 & 27.0 & 57.9 & 3.2 & 38.9 & 31.9 & 68.1 & 0.0 & 28.1 & 28.1 & 43.8 & 1.5 & 9.0 \\
\hline $141-862 \mathrm{~A}-$ & & & & & & & & & & & & & & \\
\hline $1 \mathrm{H}-2,28-29$ & 28.7 & 38.6 & 32.8 & 41.9 & 7.4 & 50.7 & 22.1 & 73.5 & 4.4 & 13.6 & 53.1 & 33.3 & 2.0 & 11.8 \\
\hline $2 \mathrm{H}-1,134-136$ & 31.8 & 32.0 & 36.2 & 47.5 & 5.4 & 47.1 & 48.9 & 51.1 & 0.0 & 32.1 & 33.9 & 33.9 & 3.5 & 4.5 \\
\hline $2 \mathrm{H}-2,23-24$ & 28.6 & 32.1 & 39.4 & 46.2 & 8.1 & 45.7 & 28.8 & 70.5 & 0.7 & 36.3 & 24.2 & 39.6 & 2.3 & 3.1 \\
\hline $2 \mathrm{H}-5,7-9$ & 29.1 & 39.1 & 31.8 & 42.1 & 8.3 & 49.6 & 24.6 & 75.4 & 0.0 & 36.1 & 30.6 & 33.3 & 2.5 & 7.6 \\
\hline $3 \mathrm{H}-2,100-102$ & 31.8 & 31.2 & 37.0 & 49.5 & 6.3 & 44.1 & 42.9 & 46.6 & 10.5 & 22.8 & 38.6 & 38.6 & 2.8 & 6.0 \\
\hline 141-862B- & & & & & & & & & & & & & & \\
\hline $2 X-1,44-46$ & 35.2 & 38.7 & 26.1 & 46.8 & 7.9 & 45.3 & 23.2 & 69.5 & 7.4 & 20.7 & 43.1 & 36.2 & 1.3 & 6.5 \\
\hline $2 X-2,127-128$ & 14.9 & 23.4 & 61.7 & 37.1 & 2.9 & 60.0 & 6.9 & 93.1 & 0.0 & 5.6 & 81.5 & 13.0 & 3.0 & 3.0 \\
\hline $2 \mathrm{X}-\mathrm{CC}, 24-26$ & 38.9 & 34.6 & 26.5 & 52.1 & 4.7 & 43.2 & 48.9 & 51.1 & 0.0 & 15.8 & 36.8 & 47.4 & 2.5 & 7.8 \\
\hline $141-863 \mathrm{~A}-$ & & & & & & & & & & & & & & \\
\hline $1 \mathrm{H}-2,124-126$ & 43.9 & 32.9 & 23.2 & 56.9 & 5.4 & 37.7 & 39.3 & 52.4 & 8.3 & 7.7 & 53.8 & 38.5 & 3.0 & 3.8 \\
\hline $1 \mathrm{H}-5,15-17$ & 39.8 & 36.5 & 23.7 & 50.9 & 9.4 & 39.7 & 41.2 & 58.8 & 0.0 & 16.7 & 30.0 & 53.3 & 1.5 & 7.1 \\
\hline 1H-CC, $27-29$ & 42.9 & 31.7 & 25.5 & 57.3 & 5.7 & 37.0 & 33.3 & 66.7 & 0.0 & 12.8 & 43.6 & 43.6 & 1.7 & 10.3 \\
\hline $2 \mathrm{H}-6,9-1 \mathrm{I}$ & 29.0 & 43.8 & 27.3 & 39.1 & 5.5 & 55.3 & 20.8 & 78.1 & 1.0 & 28.4 & 53.7 & 17.9 & 3.0 & 8.3 \\
\hline $3 \mathrm{H}-2,57-61$ & 30.2 & 38.1 & 31.7 & 42.2 & 7.8 & 50.0 & 16.3 & 75.0 & 8.8 & 21.2 & 57.7 & 21.2 & 2.7 & 10.4 \\
\hline $3 \mathrm{H}-2,128-133$ & 47.0 & 33.6 & 19.4 & 57.3 & 7.3 & 35.4 & 23.9 & 76.1 & 0.0 & 22.2 & 35.6 & 42.2 & 1.3 & 6.1 \\
\hline $7 X-4,56-59$ & 30.0 & 41.4 & 28.6 & 40.9 & 5.6 & 53.6 & 10.7 & 85.4 & 3.9 & 4.2 & 32.4 & 63.4 & 2.3 & 7.8 \\
\hline $8 X-3,91-95$ & 42.5 & 32.4 & 25.1 & 56.4 & 4.5 & 39.1 & 33.3 & 65.6 & 1.1 & 9.3 & 55.6 & 35.2 & 3.0 & 6.5 \\
\hline $9 X-C C, 13-15$ & 36.0 & 35.7 & 28.3 & 49.2 & 5.0 & 45.7 & 18.3 & 78.8 & 2.9 & 11.7 & 42.9 & 45.5 & 1.5 & 4.6 \\
\hline $10 X-C C, 25-27$ & 40.1 & 40.9 & 19.0 & 49.5 & 5.8 & 44.7 & 31.9 & 68.1 & 0.0 & 2.4 & 57.1 & 40.5 & 0.0 & 9.1 \\
\hline $11 \mathrm{X}-\mathrm{CC}, 6-7$ & 30.4 & 47.1 & 22.4 & 38.3 & 10.9 & 50.7 & 16.9 & 83.1 & 0.0 & 11.1 & 50.0 & 38.9 & 1.0 & 10.6 \\
\hline $14 X-2,31-36$ & 30.6 & 39.3 & 30.1 & 43.1 & 9.3 & 47.6 & 12.1 & 87.9 & 0.0 & 9.4 & 42.4 & 48.2 & 1.5 & 8.8 \\
\hline $17 \mathrm{X}-\mathrm{CC}, 17-20$ & 27.9 & 46.7 & 25.4 & 36.9 & 8.2 & 54.9 & 22.8 & 77.2 & 0.0 & 4.9 & 50.8 & 44.3 & 2.3 & 7.3 \\
\hline $19 X-1,48-51$ & 34.7 & 30.6 & 34.7 & 51.9 & 11.0 & 37.1 & 25.6 & 45.0 & 29.5 & 10.8 & 56.8 & 32.4 & 2.3 & 3.0 \\
\hline $24 X-1,10-12$ & 35.4 & 37.0 & 27.6 & 48.6 & 8.1 & 43.2 & 25.3 & 72.7 & 2.0 & 22.2 & 35.2 & 42.6 & 1.0 & 5.5 \\
\hline $26 \mathrm{X}-\mathrm{CC}, 14-16$ & 30.5 & 37.9 & 31.6 & 44.2 & 4.6 & 51.3 & 15.2 & 80.4 & 4.5 & 12.2 & 52.4 & 35.4 & 2.5 & 7.8 \\
\hline $28 X-1,69-71$ & 25.6 & 25.3 & 49.1 & 49.2 & 11.4 & 39.5 & 26.4 & 46.2 & 27.5 & 24.3 & 54.3 & 21.4 & 0.5 & 4.3 \\
\hline $28 \mathrm{X}-1,105-108$ & 27.5 & 42.0 & 30.5 & 39.0 & 7.3 & 53.7 & 24.8 & 74.3 & 0.9 & 14.5 & 40.8 & 44.7 & 2.0 & 8.1 \\
\hline $28 \mathrm{X}-\mathrm{CC}, 19-22$ & 28.4 & 35.8 & 35.8 & 43.9 & 4.5 & 51.6 & 17.6 & 78.4 & 4.0 & 19.5 & 54.5 & 26.0 & 3.5 & 6.8 \\
\hline
\end{tabular}


PROVENANCE OF PLEISTOCENE AND PLIOCENE SAND

APPENDIX 2 (continued).

\begin{tabular}{|c|c|c|c|c|c|c|c|c|c|c|c|c|c|c|}
\hline \multirow{2}{*}{$\begin{array}{l}\text { Core, section, } \\
\text { interval }(\mathrm{cm})\end{array}$} & \multicolumn{3}{|c|}{$\mathrm{QFL}$} & \multicolumn{3}{|c|}{ QmKP } & \multicolumn{3}{|c|}{ LmLvLs } & \multicolumn{3}{|c|}{ LvclLvbrLvbl } & \multirow{2}{*}{$\begin{array}{l}\text { FR\% } \\
\text { Mica }\end{array}$} & \multirow{2}{*}{$\begin{array}{l}\text { Fr\% } \\
\text { D }\end{array}$} \\
\hline & $\% Q$ & $\% \mathrm{~F}$ & $\% \mathrm{~L}$ & $\% \mathrm{Qm}$ & $\% \mathrm{~K}$ & $\% \mathrm{P}$ & $\% \mathrm{Lm}$ & $\% \mathrm{Lv}$ & \%Ls & \%Lvcl & \%Lvbr & $\%$ Lvbl & & \\
\hline $29 X-2,25-28$ & 26.4 & 42.9 & 30.7 & 37.1 & 6.7 & 56.3 & 24.1 & 69.4 & 6.5 & 8.8 & 47.4 & 43.9 & 1.0 & 10.8 \\
\hline $30 \times-1,3-7$ & 25.9 & 39.8 & 34.4 & 38.6 & 9.2 & 52.2 & 13.2 & 82.6 & 4.1 & 34.2 & 39.2 & 26.6 & 1.5 & 9.0 \\
\hline $30 X-C C, 20-22$ & 28.6 & 43.1 & 28.3 & 39.4 & 5.0 & 55.6 & 18.4 & 79.6 & 1.9 & 42.9 & 40.0 & 17.1 & 1.0 & 7.8 \\
\hline $31 X-1,3-4$ & 30.2 & 34.6 & 35.1 & 45.7 & 6.8 & 47.4 & 29.5 & 65.9 & 4.7 & 33.3 & 48.5 & 18.2 & 1.0 & 4.8 \\
\hline $31 X-1,41-43$ & 24.1 & 42.1 & 33.8 & 34.5 & 9.1 & 56.5 & 15.6 & 77.9 & 6.6 & 12.0 & 50.7 & 37.3 & 1.0 & 8.1 \\
\hline \multicolumn{15}{|l|}{$141-863 \mathrm{~A}-$} \\
\hline $4 X-1,23-26$ & 36.7 & 38.8 & 24.5 & 48.0 & 7.4 & 44.5 & 31.0 & 63.1 & 6.0 & 16.3 & 32.6 & 51.2 & 0.3 & 13.3 \\
\hline $4 X-2,1-3$ & 50.9 & 35.7 & 13.4 & 58.2 & 7.6 & 34.1 & 28.2 & 69.2 & 2.6 & 13.3 & 46.7 & 40.0 & 0.0 & 3.0 \\
\hline $4 X-4,129-134$ & 33.3 & 37.4 & 29.2 & 46.7 & 10.5 & 42.8 & 38.3 & 57.9 & 3.7 & 12.0 & 40.0 & 48.0 & 1.5 & 6.5 \\
\hline $4 X-5,2-7$ & 33.1 & 33.9 & 33.1 & 49.4 & 10.8 & 39.8 & 25.0 & 54.0 & 21.0 & 9.3 & 48.1 & 42.6 & 1.3 & 4.8 \\
\hline $7 \mathrm{~N}-\mathrm{CC}, 4-6$ & 20.9 & 23.5 & 55.6 & 45.5 & 2.6 & 51.9 & 13.6 & 28.6 & 57.8 & 12.8 & 48.9 & 38.3 & 1.5 & 5.5 \\
\hline $8 \mathrm{~N}-1,5-7$ & 32.1 & 29.6 & 38.4 & 51.8 & 8.0 & 40.2 & 35.0 & 25.0 & 40.0 & 14.3 & 71.4 & 14.3 & 0.3 & 8.1 \\
\hline $10 \mathrm{R}-1,68-71$ & 25.4 & 26.2 & 48.4 & 48.1 & 6.9 & 45.0 & 24.9 & 43.1 & 32.0 & 6.5 & 63.0 & 30.4 & 0.5 & 4.3 \\
\hline $12 \mathrm{R}-1,38-40$ & 23.0 & 19.3 & 57.8 & 53.8 & 5.8 & 40.4 & 16.2 & 20.8 & 63.0 & 0.0 & 38.1 & 61.9 & 0.0 & 5.3 \\
\hline $13 \mathrm{R}-1,41-43$ & 33.3 & 31.5 & 35.2 & 50.6 & 6.2 & 43.2 & 20.1 & 39.6 & 40.3 & 13.3 & 60.0 & 26.7 & 0.3 & 3.8 \\
\hline $15 \mathrm{R}-1,1-3$ & 15.4 & 12.6 & 72.0 & 54.2 & 11.2 & 34.6 & 16.8 & 7.5 & 75.7 & 37.5 & 50.0 & 12.5 & 0.8 & 0.5 \\
\hline $16 \mathrm{R}-4,130-133$ & 31.8 & 27.7 & 40.5 & 53.0 & 5.4 & 41.6 & 29.5 & 29.5 & 41.0 & 11.1 & 22.2 & 66.7 & 0.5 & 13.3 \\
\hline $17 \mathrm{R}-7,20-25$ & 16.0 & 16.7 & 67.2 & 48.4 & 11.8 & 39.8 & 18.7 & 20.7 & 60.6 & 100.0 & 0.0 & 0.0 & 0.3 & 1.3 \\
\hline $19 \mathrm{R}-3,102-105$ & 30.7 & 27.6 & 41.7 & 51.9 & 8.7 & 39.4 & 47.7 & 21.9 & 30.5 & 22.2 & 55.6 & 22.2 & 1.0 & 5.6 \\
\hline 2 IR-1, 72-75 & 27.6 & 33.1 & 39.3 & 45.3 & 4.9 & 49.8 & 22.8 & 41.4 & 35.9 & 0.0 & 44.4 & 55.6 & 0.3 & 4.6 \\
\hline $22 \mathrm{R}-1,81-83$ & 28.4 & 33.8 & 37.8 & 44.2 & 6.2 & 49.6 & 24.1 & 57.4 & 18.4 & 3.3 & 26.7 & 70.0 & 0.8 & 6.0 \\
\hline $24 \mathrm{R}-3,11-13$ & 28.0 & 41.8 & 30.2 & 39.6 & 6.9 & 53.5 & 27.1 & 57.9 & 15.0 & 3.4 & 65.5 & 31.0 & 0.5 & 9.6 \\
\hline $25 \mathrm{R}-2,111-114$ & 35.3 & 39.1 & 25.6 & 47.3 & 6.2 & 46.5 & 16.8 & 57.9 & 25.3 & 6.7 & 80.0 & 13.3 & 1.8 & 4.0 \\
\hline $32 \mathrm{R}-5,38-40$ & 34.0 & 38.8 & 27.2 & 45.8 & 5.6 & 48.6 & 17.6 & 57.4 & 25.0 & 10.0 & 30.0 & 60.0 & 0.4 & 4.4 \\
\hline $34 \mathrm{R}-5,70-73$ & 34.3 & 39.4 & 26.3 & 46.4 & 8.8 & 44.9 & 22.4 & 53.1 & 24.5 & 10.0 & 40.0 & 50.0 & 2.0 & 2.8 \\
\hline $35 \mathrm{R}-1,4-6$ & 36.4 & 43.6 & 20.0 & 45.2 & 8.3 & 46.6 & 32.9 & 61.6 & 5.5 & 20.0 & 50.0 & 30.0 & 0.8 & 7.3 \\
\hline $37 \mathrm{R}-4,77-80$ & 36.4 & 36.4 & 27.2 & 49.8 & 6.4 & 43.8 & 23.4 & 59.6 & 17.0 & 14.8 & 40.7 & 44.4 & 0.5 & 11.5 \\
\hline $39 R-2,105-107$ & 23.1 & 43.7 & 33,2 & 34.6 & 8.9 & 56.4 & 16.9 & 60.7 & 22.5 & 0.0 & 76.2 & 23.8 & 0.4 & 5.6 \\
\hline $42 \mathrm{R}-2,62-64$ & 33.0 & 36.5 & 30.6 & 46.5 & 8.3 & 45.3 & 28.1 & 34.2 & 37.7 & 0.0 & 27.8 & 72.2 & 0.8 & 5.5 \\
\hline $43 R-2,73-75$ & 33.2 & 31.8 & 35.1 & 50.4 & 11.0 & 38.6 & 23.3 & 41.1 & 35.7 & 14.3 & 25.0 & 60.7 & 2.8 & 4.3 \\
\hline $44 R-5,43-46$ & 32.4 & 41.8 & 25.7 & 42.9 & 6.2 & 50.9 & 28.1 & 56.3 & 15.6 & 4.7 & 48.8 & 46.5 & 1.0 & 5.5 \\
\hline $45 R-2,60-63$ & 35.5 & 43.8 & 20.7 & 44.4 & 11.2 & 44.4 & 37.3 & 50.7 & 12.0 & 22.7 & 77.3 & 0.0 & 2.3 & 6.3 \\
\hline $46 \mathrm{R}-2,62-66$ & 26.0 & 23.3 & 50.7 & 51.9 & 8.3 & 39.8 & 15.3 & 12.7 & 72.0 & 0.0 & 64.3 & 35.7 & 0.8 & 3.8 \\
\hline $47 \mathrm{R}-1,111-122$ & 29.5 & 29.1 & 41.4 & 49.1 & 8.2 & 42.8 & 27.8 & 32.2 & 40.0 & 18.2 & 54.5 & 27.3 & 0.0 & 2.7 \\
\hline $49 \mathrm{R}-1,86-89$ & 31.7 & 41.0 & 27.2 & 43.0 & 6.3 & 50.7 & 21.4 & 40.8 & 37.9 & 0.0 & 31.3 & 68.8 & 0.5 & 3.3 \\
\hline
\end{tabular}



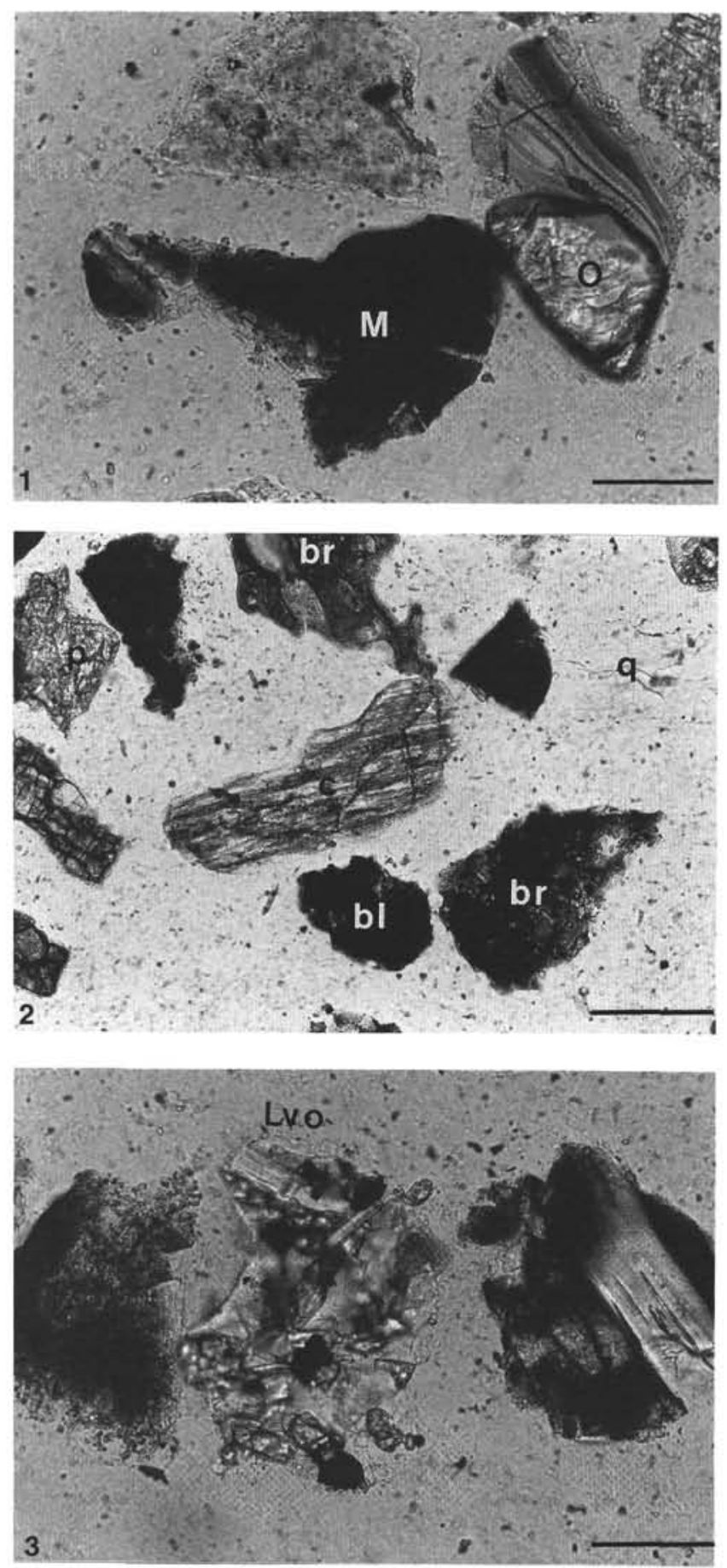

Plate 1. Photomicrographs, all plane-polarized light. Note that stained brown glass appears darker than unstained brown glass. 1. Olivine in light brown glassy fragment with flow texture $(\mathrm{O})$ and dark brown microlitic fragment $(\mathrm{M})$. Unstained slide. Sample 141-860B-6H-6, 60-63 cm. Scale bar $=0.12 \mathrm{~mm} .2$. Dark brown microlitic (br, bottom right) and vesicular vitric (br, top center), black microlitic (bl), and clear vitric (q) fragments. Stained slide. Sample 141-860B-6H-3, 76-79 cm. Scale bar $=0.51 \mathrm{~mm}$. 3. Holocrystalline aggregate (Lvo) of feldspar, opaques, and pyroxene, flanked by black microlitic (left) and lathwork (right) fragments. Unstained slide. Sample 141-860B-6H-3, $76-79 \mathrm{~cm}$. Scale bar $=0.12 \mathrm{~mm}$.
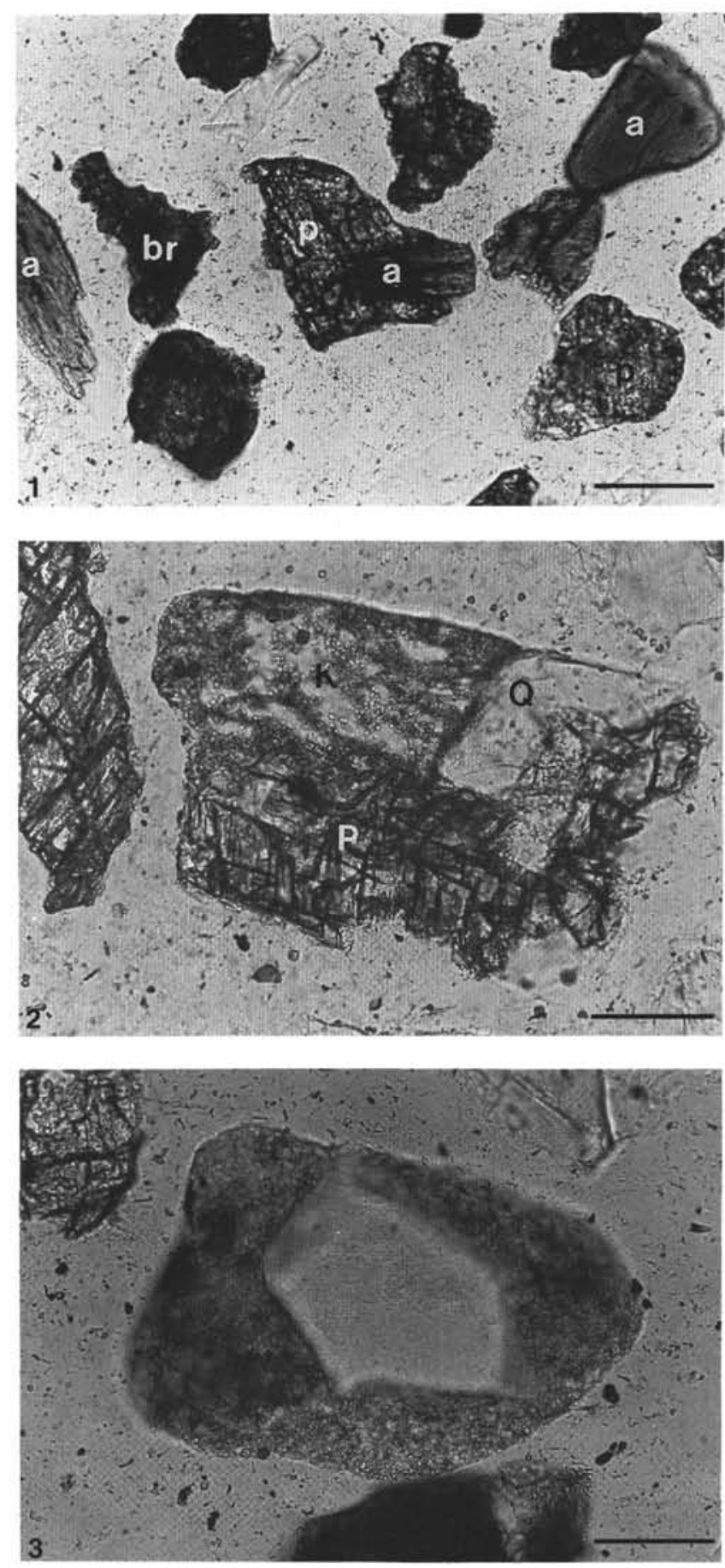

Plate 2. Photomicrographs, all plane-polarized light. 1. Plagioclase (p) and amphibole (a) aggregate (an Lvo fragment), amphibole (a) and plagioclase (p) crystals, and microlitic brown glass fragment (br). Stained slide. Sample 141-860B-6H-6, 60-63 cm. Scale bar $=0.51 \mathrm{~mm}$. 2. Coarse plutonic fragment composed of quartz $(\mathrm{Q}), \mathrm{K}$-feldspar $(\mathrm{K})$, and plagioclase $(\mathrm{P})$. Stained slide. Sample $141-860 \mathrm{~B}-6 \mathrm{H}-3,76-79 \mathrm{~cm}$. Scale bar $=0.12 \mathrm{~mm}$. 3. Felsitic volcanic lithic with quartz phenocryst. Unstained slide. Sample 141-860B-6H$6,60-63 \mathrm{~cm}$. Scale bar $=0.12 \mathrm{~mm}$. 

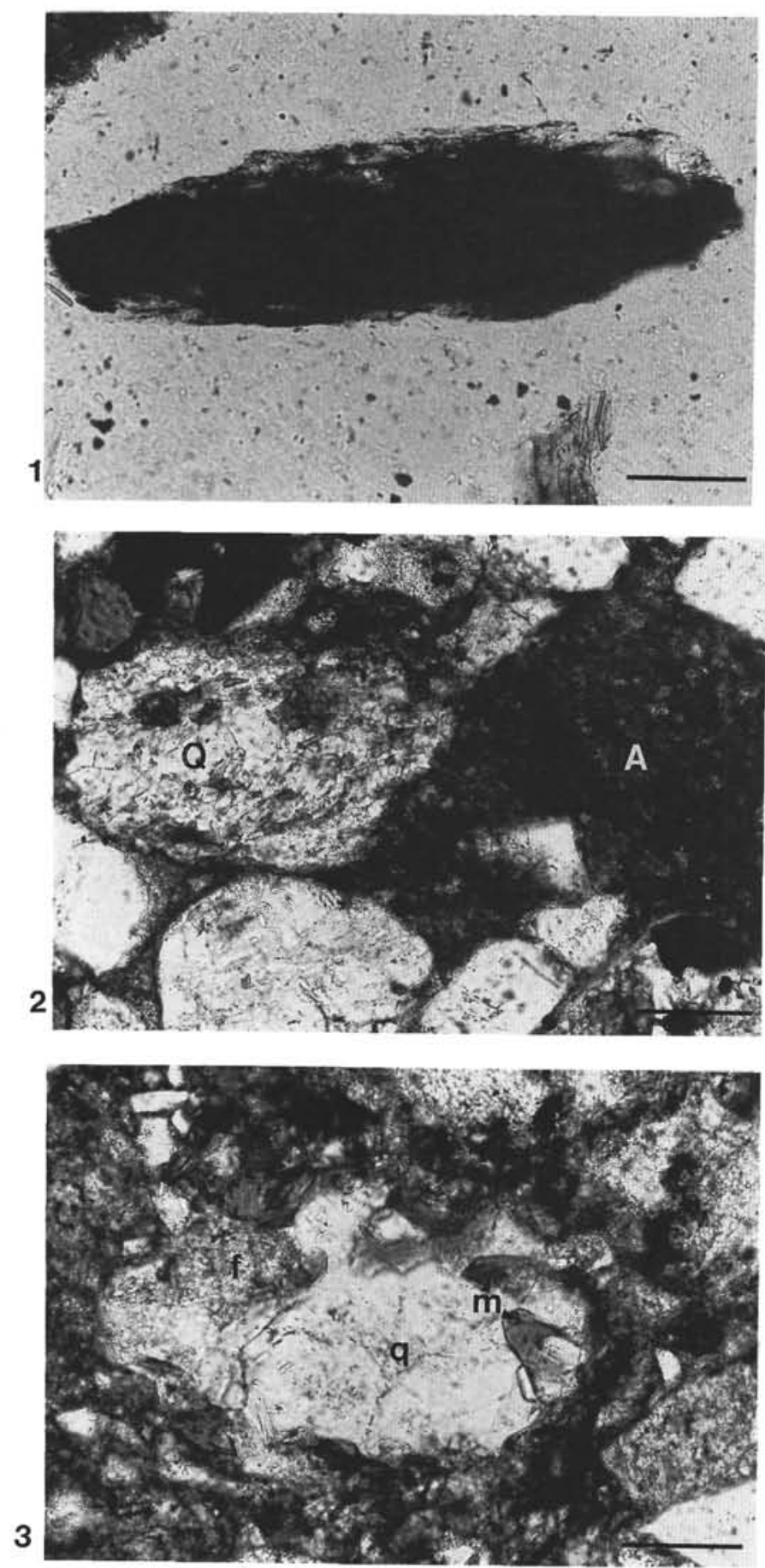

Plate 3. Photomicrographs, all plane-polarized light. 1. Graphitic schist fragment (center). Unstained slide. Sample 141-860B-6H-3, 76-79 cm. Scale bar $=0.12 \mathrm{~mm}$. 2. Argillite $(A)$ and quartz schist with red biotite $(Q)$ fragments. Unstained slide. Sample 141-863B-4X-1, 23-26 cm. Scale bar $=0.12$ $\mathrm{mm}$. 3. Fragment of quartz-mica-feldspar $(\mathrm{q}, \mathrm{m}, \mathrm{f})$ aggregate. Unstained slide. Sample 141-863B-19R-3, 102-105 cm. Scale bar $=0.51 \mathrm{~mm}$.
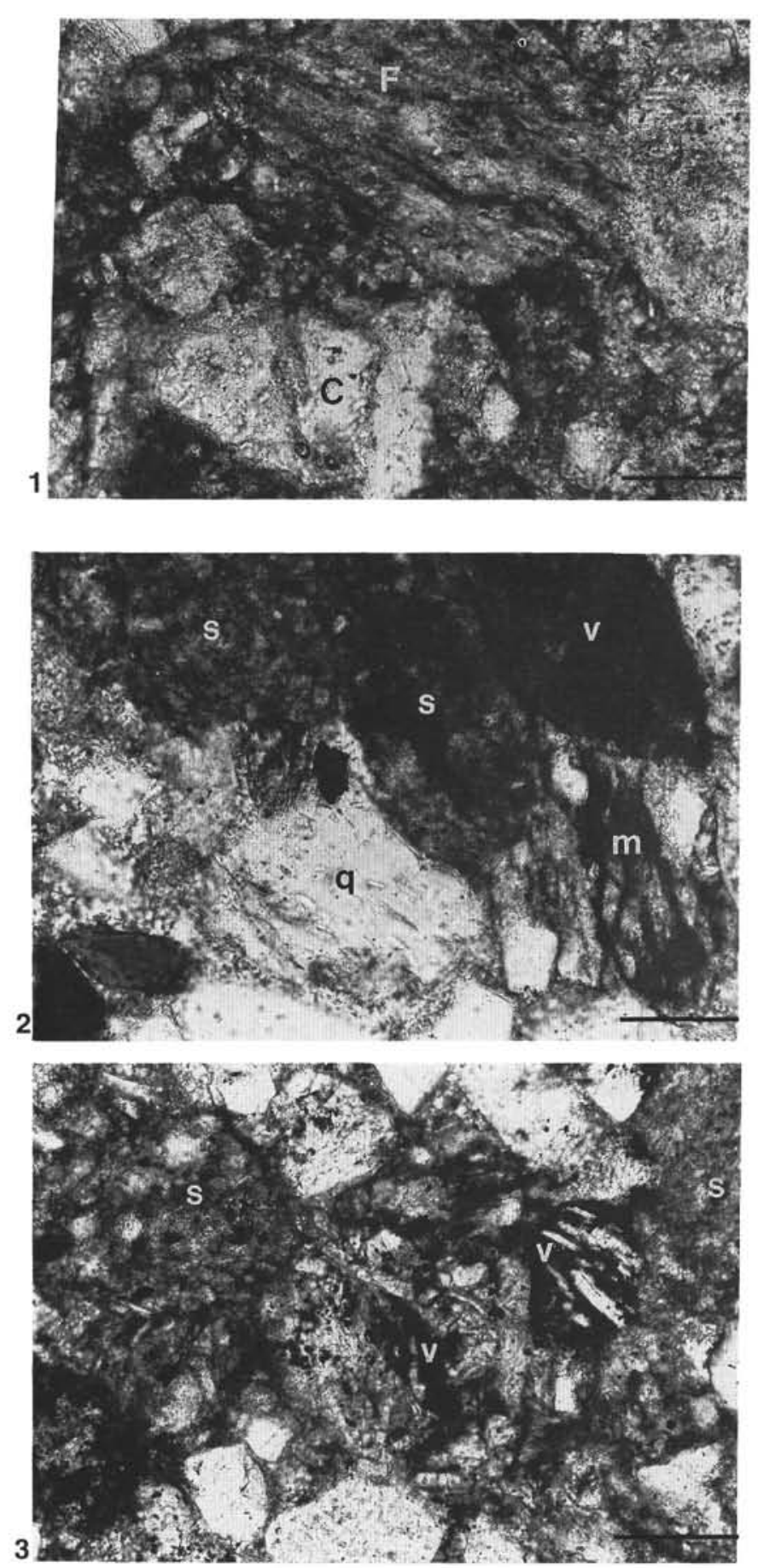

Plate 4. Photomicrographs, all plane-polarized light. 1. Coarse- (C) and fine-grained $(\mathrm{F})$ metasedimentary fragments. Unstained slide. Sample 141863B-19R-3, $102-105 \mathrm{~cm}$. Scale bar $=0.51 \mathrm{~mm}$. 2. Sedimentary (s), altered volcanic (v), quartz-dominated quartz mica tectonite $(\mathrm{q})$, and mica-dominated quartz mica tectonite $(\mathrm{m})$ fragments. Unstained slide. Sample 141-863B-47R$1,111-122 \mathrm{~cm}$. Scale $=0.51 \mathrm{~mm}$. 3. Sedimentary $(\mathrm{s})$ and altered volcanic $(v)$ lithic fragments. Unstained slide. Sample 141-863B-47R-1, 111-122 cm. Scale bar $=0.51 \mathrm{~mm}$. 